Review

\title{
Dietary Polyphenols and Their Biological Significance
}

\author{
Xiuzhen Han, Tao Shen and Hongxiang Lou* \\ Department of Natural Product Chemistry, School of Pharmaceutical Sciences, Shandong University, \\ 44 West Wenhua Road, Jinan 250012, P. R. China; E-mails: xzyhan@sina.com (X. Han); \\ v.shentao@yahoo.com.cn (T. Shen) \\ * Author to whom correspondence should be addressed; E-mail: louhongxiang@sdu.edu.cn; \\ Tel.: (+86)-531-88382012; Fax: (+86)-531-88382019
}

Received: 12 June 2007; in revised form: 27 August 2007 / Accepted: 27 August 2007 /

Published: 12 September 2007

\begin{abstract}
Dietary polyphenols represent a wide variety of compounds that occur in fruits, vegetables, wine, tea, extra virgin olive oil, chocolate and other cocoa products. They are mostly derivatives and/or isomers of flavones, isoflavones, flavonols, catechins and phenolic acids, and possess diverse biological properties such as antioxidant, antiapoptosis, anti-aging, anticarcinogen, anti-inflammation, anti-atherosclerosis, cardiovascular protection, improvement of the endothelial function, as well as inhibition of angiogenesis and cell proliferation activity. Most of these biological actions have been attributed to their intrinsic reducing capabilities. They may also offer indirect protection by activating endogenous defense systems and by modulating cellular signaling processes such as nuclear factor-kappa B (NF-кB) activation, activator protein-1(AP-1) DNA binding, glutathione biosynthesis, phosphoinositide 3 (PI3)-kinase/protein kinase B (Akt) pathway, mitogen-activated protein kinase (MAPK) proteins [extracellular signal-regulated protein kinase (ERK), c-jun N-terminal kinase (JNK) and P38 ] activation, and the translocation into the nucleus of nuclear factor erythroid 2 related factor 2 (Nrf2). This paper covers the most recent literature on the subject, and describes the biological mechanisms of action and protective effects of dietary polyphenols.
\end{abstract}

Keywords: Polyphenols; antioxidant; anticarcinogen; antiapoptosis; cardiovascular protection; Nrf2; NF-кB; biological properties. 


\section{Introduction}

Oxidative stress results in oxidative alteration of biological macromolecules such as lipids, proteins and nucleic acids. It is considered to play a pivotal role in the pathogenesis of aging and degenerative diseases [1-3]. In order to cope with an excess of free radicals produced upon oxidative stress, human bodies have developed sophisticated mechanisms for maintaining redox homeostasis. These protective mechanisms include scavenging or detoxification of reactive oxygen species (ROS), blocking ROS production, sequestration of transition metals, as well as enzymatic and nonenzymatic antioxidant defenses produced in the body, that is, endogenous [4,5], and others supplied with the diet, namely, exogenous ones. Among them, dietary polyphenols have been widely studied for their strong antioxidant capacities and other properties by which cell functions are regulated $[6,7]$.

Dietary polyphenols represent a group of secondary metabolites which widely occur in fruits, vegetables, wine, tea, extra virgin olive oil, chocolate and other cocoa products. They are mostly derivatives, and/or isomers of flavones, isoflavones, flavonols, catechins, and phenolic acids. Dietary polyphenols exhibit many biologically significant functions, such as protection against oxidative stress, and degenerative diseases. Experimental data indicate that most of these biological actions can be attributed to their intrinsic antioxidant capabilities. Dietary polyphenols may offer an indirect protection by activating endogenous defense systems and by modulating cellular signaling processes such as NF-кB activation, AP-1 DNA binding, glutathione biosynthesis, PI3-kinase/Akt pathway, MAPK proteins (ERK, JNK and P38) activation, and the translocation into the nucleus of Nrf2 [8-10].

\section{Classification and occurrence of dietary polyphenols}

Dietary polyphenols are the most abundant antioxidants in human diets. With over 8,000 structural variants, they are secondary metabolites of plants and denote many substances with aromatic ring(s) bearing one or more hydroxyl moieties. They are subdivided into groups (Figure 1) by the number of phenolic rings and of the structural elements that link these rings [11]: (1) The phenolic acids with the subclasses derived from hydroxybenzoic acids such as gallic acid and from hydroxycinnamic acid, containing caffeic, ferulic, and coumaric acid; (2) the large flavonoid subclass, which includes the flavonols, flavones, isoflavones, flavanones, anthocyanidins, and flavanols; (3) the stilbenes; and (4) the lignans and the polymeric lignins.

The main dietary sources of polyphenols include some common fruits, vegetables and beverages. Phenolic acids account for about one third of the total intake and flavonoids account for the remaining two thirds. The most abundant flavonoids in the diet are flavanols (catechins plus proanthocyanidins), anthocyanins and their oxidation products. The main polyphenol dietary sources are fruit and beverages (fruit juice, wine, tea, coffee, chocolate and beer) and, to a lesser extent vegetables, dry legumes and cereals. Most of dietary polyphenols and their sources in our diets were shown in Table 1.

\subsection{Phenolic acids}

A major class within the phenolic compounds is the hydroxycinnamic acids, which are widely distributed in plant kingdom. The major hydroxycinnamic acid is caffeic acid, which occurs in foods mainly as an ester with quinic acid called chlorogenic acid (5-caffeoylquinic acid). Chlorogenic acid 
and caffeic acid are antioxidants in vitro and they might inhibit the formation of mutagenic and carcinogenic $N$-nitroso compounds for the inhibitory effect on the $N$-nitrosation reaction in vitro.

Figure 1. Classification of dietary polyphenols.

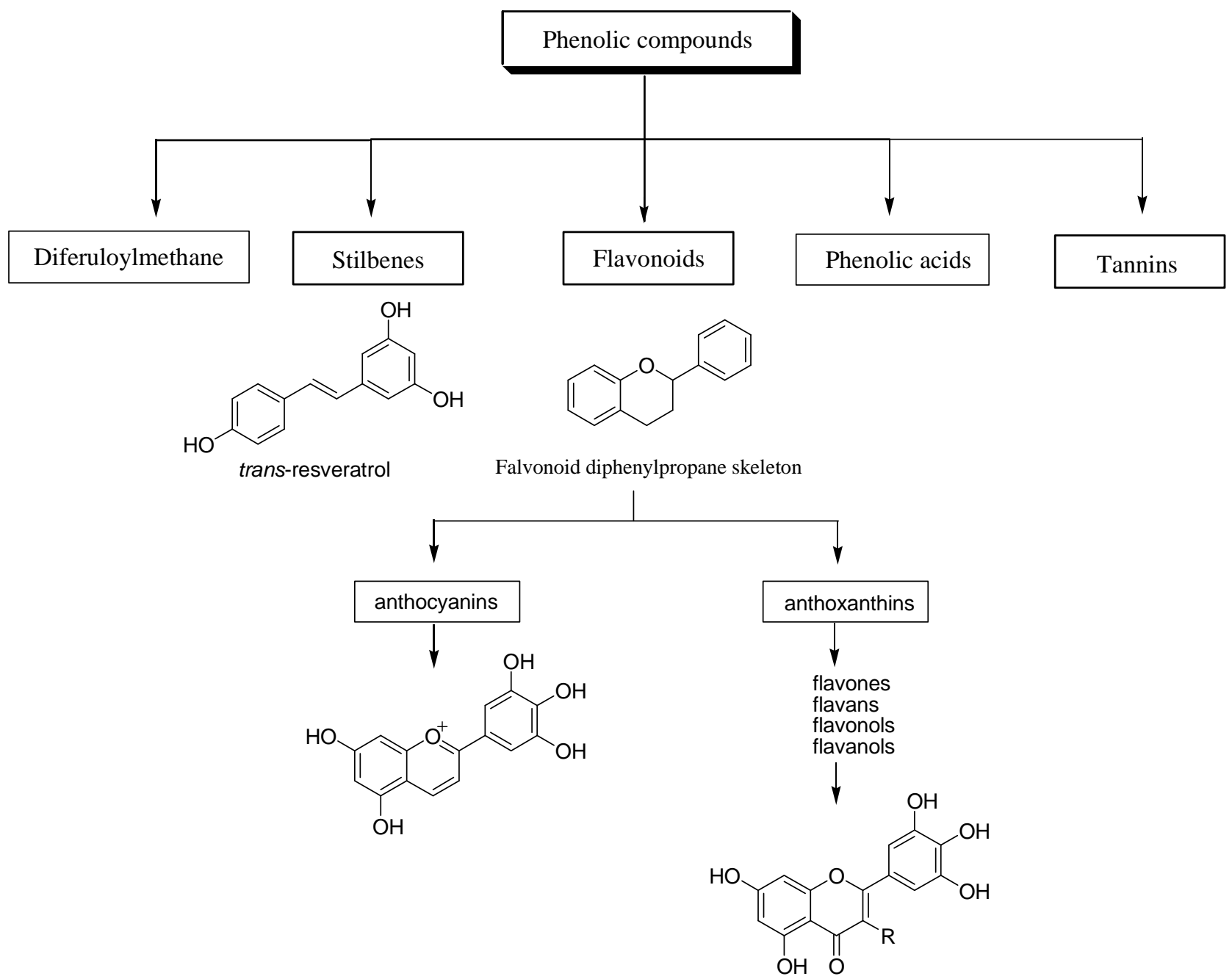

\subsection{Flavonoids}

Flavonoids are the most abundant polyphenols in human diets, and are mainly divided into: (a) anthocyanins, glycosylated derivative of anthocyanidin, present in colorful flowers and fruits; (b) anthoxanthins, a group of colorless compounds further divided in several categories, including flavones, flavans, flavonols, flavanols, isoflavones, and their glycosides. Flavonols are mainly represented by myricetin, fisetin, quercetin and kaempferol.

\subsection{Stilbenes}

Stibenes are structurally characterized by the presence of a 1,2-diphenylethylene nucleus with hydroxyls substitued on the aromatic rings, and exist in the form of monomers or oligomers. The best known compound is trans-resveratrol, possessing a trihydroxystilbene skelelton. 


\subsection{Tannins}

Tannins are a group of water-soluble polyphenols having molecular weights from 500 to 3,000 which are subdivided into condensed and hydrolisable tannins, and commonly found complexed with alkaloids, polysaccharides and proteins, particularly the latter. On the basis of structural characteristics there are two groups, gallotannins and ellagitannins of hydrolysable tannins.

\subsection{Diferuloylmethanes}

Diferuloylmethanes are a small group of phenolic compounds with two aromatic rings substitued with hydroxyls, and linked by aliphatic chain containing carbonyl groups. There are also some other polyphenols such as hydroxytyrosol, a simple polyphenol presenting in olive fruits and olive oil $[12,13]$.

Table 1. Classification and sources of dietary polyphenols

\begin{tabular}{|c|c|c|c|}
\hline Class and subclass & Dietary polyphenol & Foods or beverages & Ref \\
\hline $\begin{array}{l}\text { Flavonoids } \\
\text { Anthocyanidins }\end{array}$ & $\begin{array}{l}\text { Cyanidin 3-galactoside } \\
\text { Cyanidin 3-glucoside } \\
\text { Cyanidin 3-arabinoside } \\
\text { Cyanidin 3-xyloside } \\
\text { Malvidin } \\
\text { Delphinidin } \\
\text { Pelargonidin }\end{array}$ & $\begin{array}{l}\text { Fruits: blackberries,black currant,blueberries, black grape, } \\
\text { elderberries,strawberries, cherries, plums, cranberry, pomegranate } \\
\text { juice, raspberry } \\
\text { Others: red wine }\end{array}$ & $\begin{array}{l}6 \\
14 \\
15 \\
16\end{array}$ \\
\hline $\begin{array}{l}\text { Anthoxanthins } \\
\text { Flavonols }\end{array}$ & $\begin{array}{l}\text { Myricetin } \\
\text { Fisetin } \\
\text { Quercetin } \\
\text { Kaempferol } \\
\text { Isorhamnetin }\end{array}$ & $\begin{array}{l}\text { Vegetables: capers, celery, chives, onions, red onions, dock leaves, } \\
\text { fennel, hot peppers,cherry tomatoes, spinach, sweet potato leaves, } \\
\text { lettuce, celery, broccoli, Hartwort leaves, kale } \\
\text { Cereal: buckwheat, beans(green/yellow) } \\
\text { Fruits: apples, apricots, grapes, plums, bilberries, blackberries, } \\
\text { blueberries, cranberries, olive elderberries, currants, cherries, black } \\
\text { currant juice, apple juice, ginkgo biloba } \\
\text { Spices and herbs: dill weed } \\
\text { Others: red wine, tea (green, black), tea (black beverage), cocoa } \\
\text { powder, turnip (green), endive, leek }\end{array}$ & $\begin{array}{l}7 \\
17 \\
14\end{array}$ \\
\hline Flavanones & $\begin{array}{l}\text { Naringenin } \\
\text { Eriodictyol } \\
\text { Hesperetin }\end{array}$ & $\begin{array}{l}\text { Citrus fruits and juices: lemon, lemon juice, lime juice, orange, } \\
\text { orange juice, grapefruit, tangerine juice } \\
\text { Spices and herbs: peppermint }\end{array}$ & $\begin{array}{l}18 \\
19 \\
20\end{array}$ \\
\hline Flavones & $\begin{array}{l}\text { Apigenin } \\
\text { Luteolin }\end{array}$ & $\begin{array}{l}\text { Fruits: celery, olives } \\
\text { Vegetables: hot peppers, celery hearts, fresh parsley } \\
\text { Spices and herbs: oregano, rosemary, dry parsley, thyme }\end{array}$ & $\begin{array}{l}14 \\
21 \\
22\end{array}$ \\
\hline
\end{tabular}


Table 1. Cont.

\begin{tabular}{|c|c|c|c|}
\hline $\begin{array}{l}\text { Flavanols } \\
\text { (Flavan-3-ols) }\end{array}$ & $\begin{array}{l}\text { (+)-Catechin } \\
\text { (-)-Epicatechin } \\
\text { (-)-Epicatechin 3-gallate } \\
\text { Morin } \\
\text { (-)-Epigallocatechin } \\
\text { (-)-Epigallocatechin-3- } \\
\text { gallate } \\
\text { (+)-Gallocatechin } \\
\text { Procyanidins } \\
\text { Prodelphinidins }\end{array}$ & $\begin{array}{l}\text { Fruits: apples, apricots, grapes, peaches, nectarines, pears,plums, } \\
\text { raisins, raspberries, cherries, blackberries, blueberries, cranberries } \\
\text { Others: red wine, tea (green, black), chocolate (dark, milk), white } \\
\text { wine, cocoa }\end{array}$ & $\begin{array}{l}23 \\
24\end{array}$ \\
\hline $\begin{array}{l}\text { Isoflavones } \\
\text { (Flavans) }\end{array}$ & $\begin{array}{l}\text { Genistein } \\
\text { Daidzein } \\
\text { Equol }\end{array}$ & $\begin{array}{l}\text { Fruits: grape seed/skin } \\
\text { Others: soybean, soy nuts, soy flour/bread, tofu, miso, soy milk, tofu } \\
\text { yogurt, soy cheese/sauce/hot dog }\end{array}$ & 25 \\
\hline Flavonoid glycoside & $\begin{array}{l}\text { Rutin } \\
\text { Hesperidin } \\
\text { Naringin }\end{array}$ & Fruits: lemon, orange, orange juice, grapefruit, tangerine juice & 26 \\
\hline $\begin{array}{l}\text { Phenolic acids } \\
\text { Hydroxycinnamic acids }\end{array}$ & $\begin{array}{l}\text { Caffeic acid } \\
\text { Chlorogenic acid } \\
\text { Ferulic acid } \\
\text { Neochlorogenic acid } \\
\text { P-coumaric acid } \\
\text { Sinapic acid } \\
\text { Caftaric acids }\end{array}$ & $\begin{array}{l}\text { Fruits: bluberry, cranberry, pear, cherry(sweet), apple, orange, } \\
\text { grapefruit, cherry juice,apple juice, lemon, peach, } \\
\text { Vegetables: potato, lettuce, spinach } \\
\text { Others: coffee beans, tea, coffee, cider }\end{array}$ & 27 \\
\hline Hydroxybenzoic acids & $\begin{array}{l}\text { Ellagic acid } \\
\text { Gallic acid } \\
\text { Corilagin }\end{array}$ & $\begin{array}{l}\text { Fruits: strawberry, raspberry } \\
\text { grape juice( black/green), longan seed, pomegranate juice }\end{array}$ & $\begin{array}{l}28 \\
29\end{array}$ \\
\hline Trihydroxy-stilbenes & $\begin{array}{l}\text { Resveratrol } \\
\text { Trans-resveratrol }\end{array}$ & $\begin{array}{l}\text { Fruits: grapes, peanuts, } \\
\text { Others: red wine }\end{array}$ & $\begin{array}{l}30 \\
31\end{array}$ \\
\hline Tannins & $\begin{array}{l}\text { Catechin polymers } \\
\text { Epicatechin polymers } \\
\text { Ellagitannins } \\
\text { Proanthocyanidins } \\
\text { Casuarictin } \\
\text { Sanguin H6 } \\
\text { Tannic acids }\end{array}$ & $\begin{array}{l}\text { Fruits: grape (dark/light) seed/skin, apple juice, strawberries, } \\
\text { longan, raspberries, pomegranate, walnuts, muscadine grape, } \\
\text { muscadine grape, peach, blackberry (juices/jams/jellies), olive, plum, } \\
\text { Vegetables: chick pea, black-eyed peas, lentils, } \\
\text { Cereal: haricot bean, } \\
\text { Others: red wine, white wine, cocoa, chocolate, oak-aged red wine, } \\
\text { tea, cider, tea, coffee, immature fruits }\end{array}$ & $\begin{array}{l}14 \\
29 \\
32\end{array}$ \\
\hline Diferuloylmethane & Curcumin & herbal remedy, dietary spice turmeric & 33 \\
\hline
\end{tabular}




\section{Bioactivities of dietary polyphenols}

Oxidative stress is considered to play a pivotal role in the pathogenesis of aging and several degenerative diseases, such as atherosclerosis, cardiovascular disease, type II diabetes and cancer [1-3]. In order to cope with an excess of free radicals produced upon oxidative stress, humans have developed endogenous and exogenous mechanisms in order to maintain redox homeostasis. Among these, dietary polyphenols have been largely studied for their strong antioxidant capacities and other properties by which cell activities are regulated (Figures 2 and 3 ).

\subsection{Antioxidant and free radical scavenging properties}

In order to combat and neutralize the deleterious effects of ROS, various antioxidant strategies have evolved either by increasing the endogenous antioxidant enzyme defenses or by enhancing the non-enzymatic defenses through dietary or pharmacological means (Table 2). Dietary polyphenols have been reported to possess potent antioxidant activity by endogenous and exogenous mechanisms.

Figure 2. Bioactivities of dietary polyphenols.

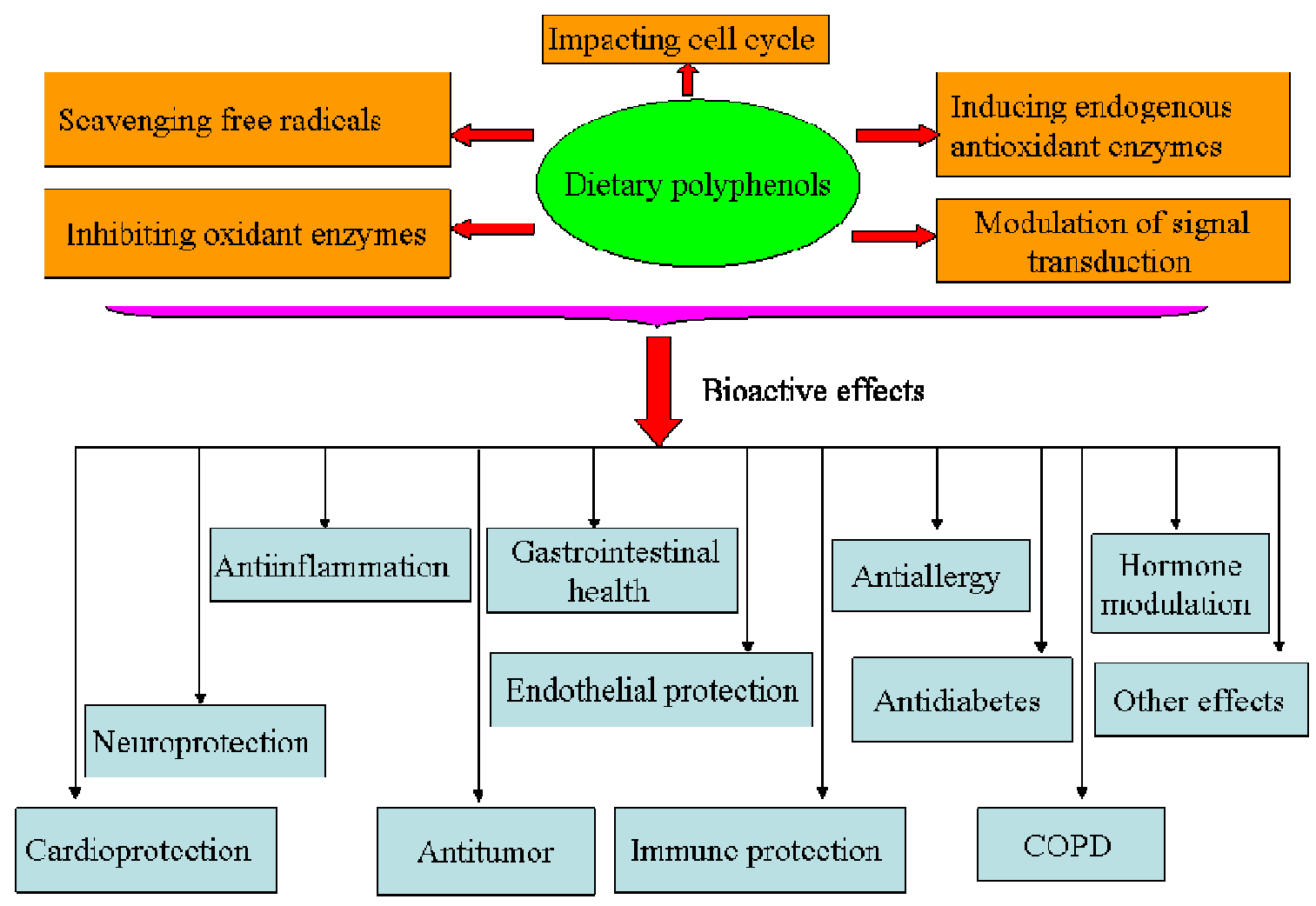

Dihydrocaffeic acid was able to scavenge free radicals (superoxide anion, hydroxyl and peroxyl radicals) in human EA.hy926 endothelial cells [42]. Curcumin and quercetin increased several antioxidant enzyme activities such as glutathione peroxidase (GPx), superoxide dismutase (SOD), catalase (CAT) or glutathione reductase (GR) in vivo and in vitro [8,9,44], and activated endogenous defense systems in vitro $[40,45]$. Hydroxytyrosol could increase CAT and SOD activities in rats fed a cholesterol-rich diet [35]. 
The transcription factor Nrf2 regulates the basal and inducible expression of numerous detoxifying and antioxidant genes. The Nrf2-Kelch-like ECH-associated protein 1 (Keap1)-ARE system is now recognized as one of the major cellular defence mechanisms against oxidative and xenobiotic stresses [46]. (-)-Epigallochatechin gallate (EGCG) and (-)-epichatechin gallate (ECG) induced ARE-mediated gene expression through the activation of MAPK proteins (ERK, JNK and p38) in HepG2-ARE-C8 cell [10]. Tanigawa et al. reported that quercetin-induced ARE activity involves upregulation of Nrf2 through the regulation of both transcription and posttranscription sites and repression of Keap1 by affecting the posttranscription site in HepG2 cells [48]. Curcumin could increase the expression of glutathione S-transferase P1 (GSTP1) by activing ARE and Nrf2 in HepG2 cells [40].

Figure 3. Mechanisms of the biological effects of dietary polyphenols.

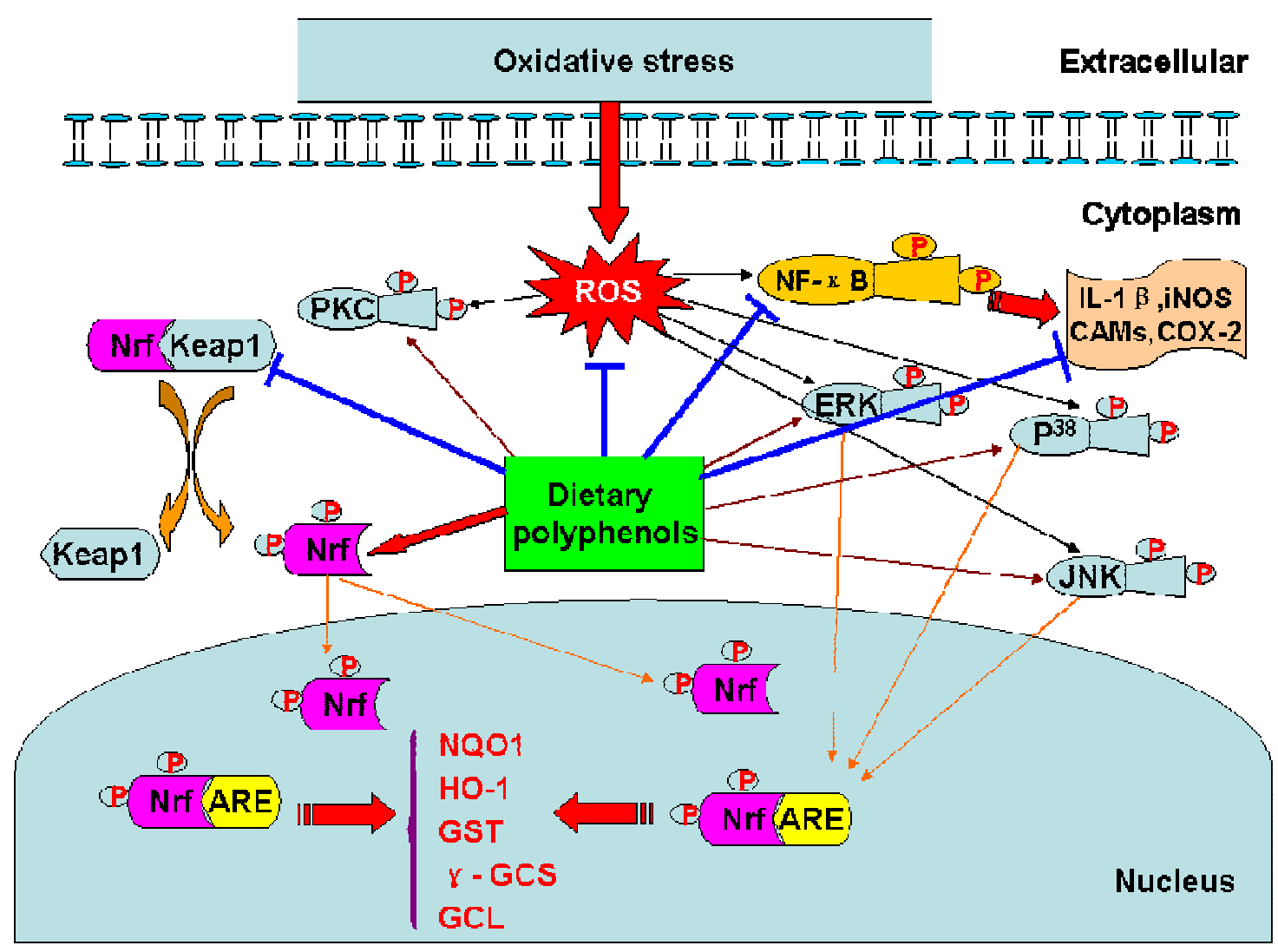

Table 2. Antioxidant and free radical scavenging properties of dietary polyphenols.

\begin{tabular}{|c|c|c|c|c|}
\hline Dietary polyphenols & Protective effects and mechanisms & Conditions & Levels & Ref \\
\hline $\begin{array}{l}\text { Epigallocatechin, } \\
\text { EGCG, ECG }\end{array}$ & Inhibiting lipoxygenase and cyclooxygenase & $\begin{array}{l}\text { In human colon mucosa and colon } \\
\text { tumor tissues }\end{array}$ & In vitro & 34 \\
\hline $\begin{array}{l}\text { EGCG } \\
\text { ECG }\end{array}$ & $\begin{array}{l}\text { Inducing ARE-mediated gene expression through } \\
\text { the activation of MAPK proteins (ERK, JNK and } \\
\text { p38) }\end{array}$ & In HepG2-ARE-C8 cell & In vitro & 10 \\
\hline \multirow[t]{2}{*}{ Hydroxytyrosol } & Increasing CAT and SOD activities & In rats fed a cholesterol-rich diet & In vivo & 35 \\
\hline & $\begin{array}{l}\text { Inhibiting the activities of 12-lipoxygenase and 5- } \\
\text { lipoxygenase } \\
\text { Reducing leukotriene B4 production }\end{array}$ & $\begin{array}{l}\text { In rat platelets and rat } \\
\text { polymorphonuclear leukocytes } \\
(\mathrm{PMNL})\end{array}$ & In vitro & 36 \\
\hline
\end{tabular}


Table 2. Cont.

\begin{tabular}{|c|c|c|c|c|}
\hline $\begin{array}{l}\text { Catechin } \\
\text { Proanthocyanidin B4 }\end{array}$ & $\begin{array}{l}\text { Increasing CAT, glutathione S-transferase (GST) } \\
\text { and SOD activities } \\
\text { Elevating cellular GSH content }\end{array}$ & In cardiac H9C2 cells & In vitro & 37 \\
\hline \multirow[t]{4}{*}{ Curcumin } & $\begin{array}{l}\text { Inhibiting CYP1A2, CYP3A4, CYP2B6, CYP2D6, } \\
\text { and CYP2C9 }\end{array}$ & $\begin{array}{l}\text { The plasmids with human } \\
\text { cytochrome P450 NADPH } \\
\text { reductase }\end{array}$ & In vitro & 38 \\
\hline & $\begin{array}{l}\text { Inhibiting mitochondrial proton F0F1-ATPase/ATP } \\
\text { synthase }\end{array}$ & Rat brain F0F1-ATPase & In vitro & 39 \\
\hline & $\begin{array}{l}\text { Increasing the expression of GSTP1 by activing } \\
\text { ARE and Nrf } 2\end{array}$ & In HepG2 cells & In vivo & 40 \\
\hline & $\begin{array}{l}\text { Increasing CAT, SOD activity and heat shock } \\
\text { proteins } 70 \text { expression } \\
\text { Decreasing the activity of iNOS } \\
\text { Decreasing malondialdehyde (MDA), } \mathrm{NO}(2)(-)+ \\
\mathrm{NO}(3)(-) \text { and myeloperoxidase (MPO) level and } \\
\text { serum transaminase concentration }\end{array}$ & In rat model & In vivo & 8 \\
\hline $\begin{array}{l}\text { Kaempferol-3-O- } \\
\text { galactoside }\end{array}$ & $\begin{array}{l}\text { Inhibiting human recombinant synovial } \\
\text { phospholipase A2 (PLA2) }\end{array}$ & In mice & In vivo & 41 \\
\hline $\begin{array}{l}\text { EGCG, Quercetin, } \\
\text { Kaempferol } \\
\text { Morin, Apigenin, } \\
\text { Daidzein, ECG }\end{array}$ & $\begin{array}{l}\text { Inhibiting mitochondrial proton F0F1-ATPase/ATP } \\
\text { synthase }\end{array}$ & Rat brain F0F1-ATPase & In vitro & 39 \\
\hline $\begin{array}{l}\text { Ellagic acid Gallic } \\
\text { acid Corilagin }\end{array}$ & $\begin{array}{l}\text { Inhibiting tyrosinase, xanthine oxidase, and the } \\
\text { formation of superoxide radical }\end{array}$ & In substrate of L-tyrosine & In vitro & 29 \\
\hline Dihydrocaffeic acid & $\begin{array}{l}\text { Enhancing eNOS activity and protein expression } \\
\text { Scavenging intracellular ROS }\end{array}$ & $\begin{array}{l}\text { In human EA.hy926 endothelial } \\
\text { cells }\end{array}$ & In vitro & 42 \\
\hline $\begin{array}{l}\text { Caffeic acid } \\
(+) \text {-catechin }\end{array}$ & $\begin{array}{l}\text { Inhibiting peroxynitrite-mediated oxidation of } \\
\text { dopamine }\end{array}$ & In dopamine & In vitro & 43 \\
\hline \multirow[t]{5}{*}{ Quercetin } & $\begin{array}{l}\text { Preventing lactate dehydrogenase (LDH ) leakage } \\
\text { Increasing SOD, CAT, GSH, GPx, and GR activity }\end{array}$ & In mouse liver & In vivo & 9 \\
\hline & $\begin{array}{l}\text { Decreasing MDA and lipoperoxidation } \\
\text { Increasing } \mathrm{Cu} / \mathrm{Zn} \text { SOD and GPx mRNA }\end{array}$ & In HepG2 cells & In vitro & 44 \\
\hline & $\begin{array}{l}\text { Increasing the expression and activity of } \\
\text { NADPH:quinone oxidoreductase-1(NQO1) }\end{array}$ & $\begin{array}{l}\text { In the MCF-7 human breast } \\
\text { carcinoma cellse }\end{array}$ & In vitro & 45 \\
\hline & Enhancing $\gamma$-glutamylcysteine synthetase $(\gamma$-GCS) & In HepG2 cells & In vitro & 47 \\
\hline & $\begin{array}{l}\text { Enhancing the ARE binding activity and Nrf2- } \\
\text { mediated transcription activity } \\
\text { Upregulating and stabilizing Nrf2 } \\
\text { Reducing the level of Keap1 protein }\end{array}$ & In HepG2 cells & In vitro & 48 \\
\hline
\end{tabular}


Table 2. Cont.

\begin{tabular}{|c|c|c|c|c|}
\hline \multirow[t]{6}{*}{ Resveratrol } & $\begin{array}{l}\text { Inhibiting O-acetyltransferase and sulfotransferase } \\
\text { activities } \\
\text { Preventing the oxidative DNA damage }\end{array}$ & $\begin{array}{l}\text { In male Wistar rats treated with } \\
\text { potassium bromate }\end{array}$ & In vivo & 49 \\
\hline & $\begin{array}{l}\text { Inhibiting the production of } \mathrm{H}_{2} \mathrm{O}_{2} \text { and MPO activity } \\
\text { Increasing GSH levels and SOD activities } \\
\text { Decreasing the levels of MPO and oxidized GR }\end{array}$ & In mouse skin & Ex vivo & 50 \\
\hline & $\begin{array}{l}\text { Reducing PhIP-DNA-adduct formation by O- } \\
\text { acetyltransferase and sulfotransferase catalysis }\end{array}$ & $\begin{array}{l}\text { In primary cultures of human } \\
\text { mammary epithelial cells }\end{array}$ & In vitro & 51 \\
\hline & $\begin{array}{l}\text { Inhibiting the expression and activity of CYP } \\
1 \mathrm{~A} 1 / 1 \mathrm{~A} 2\end{array}$ & $\begin{array}{l}\text { In microsomes and intact HepG2 } \\
\text { cells }\end{array}$ & In vitro & 52 \\
\hline & $\begin{array}{l}\text { Inhibiting mitochondrial proton F0F1-ATPase/ATP } \\
\text { synthase }\end{array}$ & Rat brain and liver F0F1-ATPase & In vitro & 39 \\
\hline & $\begin{array}{l}\text { Suppressing CYP1A1 and IL-1 } \beta \text { transcription by } \\
\text { blocking aryl hydrocarbon receptor }\end{array}$ & & $\begin{array}{l}\text { Ex vivo } \\
\text { In vivo }\end{array}$ & 53 \\
\hline $\begin{array}{l}\text { (-)-Epicatechin } \\
\text { Procyanidin } \\
\text { EGCG, ECG }\end{array}$ & $\begin{array}{l}\text { Inhibiting recombinant human platelet 12- } \\
\text { lipoxygenase and 15-lipoxygenase }\end{array}$ & $\begin{array}{l}\text { In rabbit smooth muscle cells and } \\
\text { in J774A. } 1 \text { cells }\end{array}$ & In vitro & 54 \\
\hline
\end{tabular}

\subsection{Anti-atherosclerosis and cardioprotection}

Studies have shown that some of dietary polyphenols exerted anti-atherosclerosis and cardioprotection (Table 3). Oleuropein inhibited the oxidation of low density lipoprotein (LDL) in vitro [61]. Quercetin decreased lipid peroxidation, upregulated the expression of serum high density lipoprotein (HDL)-associated paraoxonase $1(\mathrm{PON}-1)$ in the HuH7 human hepatoma cell line [66], inhibited oxidized LDL (oxLDL)-triggered apoptosis, and increased intracellular glutathione (GSH) downregulation in COS-1 cells [68].

Proanthocyanidin could significantly reduce cardiomyocyte apoptosis by inhibiting ischemia/reperfusion-induced activation of JNK-1 and c-Jun in Male Sprague Dawley rats [74]. Furthermore, proanthocyanidin could regulate the levels of CD36 mRNA and protein in oxLDL treated peripheral blood mononuclear cells [73]. Resveratrol showed that in vitro it could decrease the expression of vascular cell adhesion molecule-1 (VCAM-1) [64], cyclooxygenase-2 (COX-2) [55], and matrix metalloproteinase-9 (MMP-9) mRNA [56] through suppression of activation of nuclear factor AP-1 [55]. Hydroxytyrosol could not only lower serum total cholesterol (TC) and low density lipoprotein cholesterol (LDL-C), but also slow the lipid peroxidation process in rats fed a cholesterolrich diet [35]. 
Table 3. Anti-atherosclerosis and cardioprotection of dietary polyphenols.

\begin{tabular}{|c|c|c|c|c|}
\hline $\begin{array}{l}\text { Dietary } \\
\text { polyphenols }\end{array}$ & Protective effects and mechanisms & Conditions & Levels & Ref \\
\hline \multirow{5}{*}{ Resveratrol } & $\begin{array}{l}\text { Suppresing the expression and activity of COX-2 } \\
\text { Suppresing activation of AP-1 }\end{array}$ & $\begin{array}{l}\text { In human mammary epithelial } \\
\text { cells }\end{array}$ & In vitro & 55 \\
\hline & Inhibiting the activity and expression of MMP-9 & In U937 cells & In vitro & 56 \\
\hline & $\begin{array}{l}\text { Enhancing myocardial angiogenesis by induction of VEGF, } \\
\text { thioredoxin-1 (Trx-1), and HO-1 }\end{array}$ & In male Sprague Dawley rats & In vivo & 57 \\
\hline & $\begin{array}{l}\text { Inhibiting the expression and binding activity of the } \\
\text { monocyte chemotactic protein-1 (MCP-1) receptor, CC- } \\
\text { chemokine receptor-2 ( CCR2) }\end{array}$ & on THP-1 monocytes & In vitro & 58 \\
\hline & $\begin{array}{l}\text { Increasing NO and NOS levels } \\
\text { Increasing intracellular cyclc GMP (cGMP) level and } \\
\text { decreasing atrial natriuretic peptide (ANP) and brain } \\
\text { natriuretic peptide (BNP) levels }\end{array}$ & $\begin{array}{l}\text { In cultured rat cardiac } \\
\text { fibroblasts }\end{array}$ & In vitro & 59 \\
\hline (-)-Epicatechin & Inhibiting $7 \beta-\mathrm{OH}$-cholesterol formation & In endothelial cells & In vitro & 60 \\
\hline \multirow[t]{2}{*}{ Hydroxytyrosol } & $\begin{array}{l}\text { Preventing platelet aggregation and eicosanoid formation } \\
\text { Inhibiting thromboxane B2 production }\end{array}$ & In platelet rich plasma & In vitro & 61 \\
\hline & Inhibit thromboxane $\mathrm{B} 2$ production & $\begin{array}{l}\text { In patients with } \\
\text { uncomplicated type I diabetes }\end{array}$ & In vivo & 62 \\
\hline $\begin{array}{l}\text { Hydroxytyrosol } \\
\text { Oleuropein } \\
\text { Caffeic acid } \\
\end{array}$ & $\begin{array}{l}\text { Inhibiting leukotriene B4 generation } \\
\text { Inhibiting 5-lipoxygenase }\end{array}$ & In rat peritoneal leukocytes & In vitro & 63 \\
\hline $\begin{array}{l}\text { Oleuropein } \\
\text { Hydroxytyrosol } \\
\text { Resveratrol } \\
\end{array}$ & $\begin{array}{l}\text { Reducing monocytoid cell adhesion to stimulated } \\
\text { endothelium } \\
\text { Decreasing VCAM-1 mRNA and protein }\end{array}$ & $\begin{array}{l}\text { In human umbilical vein } \\
\text { endothelial cells (HUVECs) }\end{array}$ & In vitro & 64 \\
\hline Oleuropein & Decreasing creatine kinase and GSH release & In the isolated rat heart & Ex vivo & 65 \\
\hline Quercetin & $\begin{array}{l}\text { Upregulating the expression of serum HDL-associated } \\
\text { PON-1 }\end{array}$ & $\begin{array}{l}\text { In the } \mathrm{HuH7} \text { human hepatoma } \\
\text { cell line }\end{array}$ & In vitro & 66 \\
\hline \multirow[t]{2}{*}{$\begin{array}{l}\text { Kaempferol } \\
\text { Apigenin }\end{array}$} & $\begin{array}{l}\text { Inducing interferon-gamma (IFN- } \gamma \text { ) gene expression } \\
\text { Downregulating IL-4 gene expression }\end{array}$ & $\begin{array}{l}\text { In peripheral blood } \\
\text { mononuclear cells }\end{array}$ & In vitro & 67 \\
\hline & $\begin{array}{l}\text { Increasing the intracellular GSH and activating } \gamma \text {-GCS } \\
\text { heavy subunit }(\mathrm{GCS}(\mathrm{h})) \text { promoter }\end{array}$ & In COS-1 cells & In vitro & 68 \\
\hline EGCG and ECG & $\begin{array}{l}\text { Inhibiting rat VSMCs adhesion on collagen and laminin } \\
\text { Interference with VSMC's integrin } \beta 1 \text { receptor and binding } \\
\text { to extracellular matrix (ECM) proteins }\end{array}$ & In rat VSMCs & In vitro & 69 \\
\hline Genistein & $\begin{array}{l}\text { Decreasing hydroxyproline concentrations } \\
\text { Suppressing the progression of myocardial fibrosis }\end{array}$ & $\begin{array}{l}\text { In Long-Evans Tokushima } \\
\text { Otsuka non-diabetic rats }\end{array}$ & In vivo & 70 \\
\hline $\begin{array}{l}\text { Genistein } \\
\text { Daidzein }\end{array}$ & $\begin{array}{l}\text { Incorporating into LDLs, increasing their oxidation } \\
\text { resistance and antiproliferative efficacy }\end{array}$ & In cultured U937 cells & Ex vivo & 71 \\
\hline
\end{tabular}


Table 3. Cont.

\begin{tabular}{|c|c|c|c|c|}
\hline Procyanidins & Decreasing leukotriene-prostacyclin ratio in plasma & $\begin{array}{l}\text { In humans and human aortic } \\
\text { endothelial cells }\end{array}$ & $\begin{array}{l}\text { In vivo } \\
\text { In vitro }\end{array}$ & 72 \\
\hline Proanthocyanidin & Inhibiting CD36 mRNA expression & $\begin{array}{l}\text { In peripheral blood } \\
\text { mononuclear cell }\end{array}$ & In vitro & 73 \\
\hline Proanthocyanidin & $\begin{array}{l}\text { Reducing cardiomyocyte apoptosis by inhibiting ischemia- } \\
\text { reperfusion-induced activation of JNK-1 and c-Jun }\end{array}$ & In Male Sprague Dawley rats & In vivo & 74 \\
\hline Hydroxytyrosol & $\begin{array}{l}\text { Lowering serum TC and LDL-C } \\
\text { Slowing the lipid peroxidation process }\end{array}$ & $\begin{array}{l}\text { In rats fed a cholesterol-rich } \\
\text { diet }\end{array}$ & In vivo & 35 \\
\hline
\end{tabular}

\subsection{Neuroprotective effects on anti-aging and neurodegenerative diseases}

Recently, there has been considerable interest in the neuroprotective effects of dietary polyphenols (Table 4), especially in the context of their modes of action as antioxidants [6]. Resveratrol had an impact on cognitive deficits by activating the phosphorylation of protein kinase $\mathrm{C}$ (PKC), secreting transthyretin to prevent $A \beta$ aggregation in cultured rat hippocampal cells [77], and stimulating AMP kinase activity in Neuro2a cells and primary neurons [75]. EGCG stimulated the deacetylase activity of recombinant silent information regulator two ortholog 1 (SIRT1) protein in human HT29 cells [80]. Curcumin could disrupt existing plaques and restore distorted neurites in an Alzheimer mouse model [84]. They had been considered as therapeutic agents for altering brain aging processes, and as possible neuroprotective agents in progressive neurodegenerative disorders such as Parkinson's and Alzheimer's diseases.

Table 4. Neuroprotective effects of dietary polyphenols.

\begin{tabular}{|c|c|c|c|c|}
\hline Dietary polyphenols & Protective effects and mechanisms & Conditions & Levels & Ref \\
\hline Hydroxytyrosol & $\begin{array}{l}\text { Attenuating } \mathrm{Fe}^{2+}-\text { and } \mathrm{NO} \text {-induced cytotoxicity } \\
\text { Increasing cellular ATP } \\
\text { Reducing lipid peroxidation } \\
\text { Hyperpolarizing basal mitochondrial membrane potential }\end{array}$ & $\begin{array}{l}\text { In murine-dissociated brain } \\
\text { cells and mice }\end{array}$ & $\begin{array}{l}\text { In vitro } \\
\text { Ex vivo }\end{array}$ & 12 \\
\hline \multirow{4}{*}{ Resveratrol } & Stimulating AMP kinase activity & $\begin{array}{l}\text { In Neuro2a cells and } \\
\text { primary neurons }\end{array}$ & In vitro & 75 \\
\hline & $\begin{array}{l}\text { Preventing fibrosis, NF- } \kappa \mathrm{B} \text { activation and TGF- } \beta \\
\text { increases induced by chronic } \mathrm{CCl}(4) \text { treatment }\end{array}$ & In rats & In vivo & 76 \\
\hline & $\begin{array}{l}\text { Activating the phosphorylation of } \mathrm{PKC} \\
\text { Secreting transthyretin to prevent } \mathrm{A} \beta \text { aggregation }\end{array}$ & $\begin{array}{l}\text { In cultured rat hippocampal } \\
\text { cells }\end{array}$ & In vitro & 77 \\
\hline & $\begin{array}{l}\text { Protecting dopaminergic neurons } \\
\text { Activating sirtuin family of NAD-dependent histone } \\
\text { deacetylases }\end{array}$ & $\begin{array}{l}\text { In organotypic midbrain } \\
\text { slice culture }\end{array}$ & In vitro & 78 \\
\hline
\end{tabular}


Table 4. Cont.

\begin{tabular}{|c|c|c|c|c|}
\hline \multirow[t]{4}{*}{$\begin{array}{l}\text { EGCG } \\
\text { ECG } \\
\text { Myricetin }\end{array}$} & $\begin{array}{l}\text { Inhibiting IL-6, IL-8, VEGF and prostaglandin E2 } \\
\text { (PGE2) production } \\
\text { Attenuating the expression of COX-2 and activation of } \\
\text { NF- } \mathrm{B} B \\
\text { Inducing the expression of MAPK phosphatase-1 } \\
\text { Suppressing the phosphorylation of MAPK (p38 and } \\
\text { JNK) }\end{array}$ & $\begin{array}{l}\text { In human astrocytoma } \\
\text { U373MG cells }\end{array}$ & In vitro & 79 \\
\hline & $\begin{array}{l}\text { Attenuating disruption of mitochondrial membrane } \\
\text { potential and release of cytochrome c } \\
\text { Decreasing the activities of caspase- } 9 \text { and caspase- } 3 \text { and } \\
\text { increase in the Bax to Bcl- } 2 \text { ratio }\end{array}$ & In rat $\mathrm{PC} 12$ cells & In vitro & 115 \\
\hline & $\begin{array}{l}\text { Stimulating the deacetylase activity of recombinant SIRT1 } \\
\text { protein }\end{array}$ & In human HT29 cells & In vitro & 80 \\
\hline & $\begin{array}{l}\text { Increasing the activities of PKC and ERK1/2 } \\
\text { Decreasing the expression of Bax, Bad, and Mdm2 } \\
\text { Increasing the expression of Bcl-2, Bcl-w, and Bcl-xL }\end{array}$ & $\begin{array}{l}\text { In human neuroblastoma } \\
\text { SH-SY5Y cell }\end{array}$ & In vitro & 81 \\
\hline $\begin{array}{l}\text { Catechin } \\
\text { Quercetin Genestein } \\
\text { Naringenin }\end{array}$ & $\begin{array}{l}\text { Attenuating the apoptotic injury induced } N \text {-methyl-4- } \\
\text { phenyl-1,2,3,6-tetrahydropyridinium hydrochloride } \\
\text { (MPP+) }\end{array}$ & $\begin{array}{l}\text { In mesencephalic dopamine } \\
\text { neurones }\end{array}$ & In vivo & 82 \\
\hline $\begin{array}{l}\text { Epicatechin } \\
\text { Kaempferol }\end{array}$ & $\begin{array}{l}\text { Protecting neurons from oxLDL-induced apoptosis by } \\
\text { inhibiting the activation of JNK, c-Jun and caspase- } 3\end{array}$ & In cultured primary neurons & In vitro & 83 \\
\hline Curcumin & $\begin{array}{l}\text { Disrupting existing plaques and restoring distorted } \\
\text { neurites } \\
\text { Crossing the blood-brain barrier and labels senile plaques } \\
\text { and cerebrovascular amyloid angiopathy }\end{array}$ & $\begin{array}{l}\text { In an Alzheimer mouse } \\
\text { model } \\
\text { In APPswe/PS1dE9 mice }\end{array}$ & In vivo & 84 \\
\hline
\end{tabular}

\subsection{Anti-inflammatory properties}

Oxidative stress induced inflammation is mediated by the activation of NF-kB and AP-1. It affects a wide variety of cellular signaling processes leading to generation of inflammatory mediators and chromatin remodeling [95,96]. The latter allows expression of pro-inflammatory genes such as interleukin-1beta (IL-1 $\beta$ ), IL-8, tumor necrotic factor alpha (TNF-a), and inducible nitric oxide synthase (iNOS). The undesired effects of oxidative stress have been found to be controlled by the antioxidant and/or anti-inflammatory effects of dietary polyphenols such as curcumin and resveratrol in vivo and in vitro [88-90,95,97] (Table 5). Resveratrol inhibited pro-inflammatory gene expression via inhibition of inhibitory $\kappa \mathrm{B}(\mathrm{I} \kappa \mathrm{B})$, thus inhibiting $\mathrm{NF}-\kappa \mathrm{B}$ transactivation, as well as restoring transrepressive pathways through the activation of histone deacetylases in RAW 264.7 cells [89]. 
Table 5. Anti-inflammatory effects of dietary polyphenols.

\begin{tabular}{|c|c|c|c|c|}
\hline Dietary polyphenols & Protective effects and mechanisms & Conditions & Levels & Ref \\
\hline Procyanidins & Inhibiting transcription and secretion of IL- $1 \beta$ & $\begin{array}{l}\text { In peripheral blood mononuclear } \\
\text { cells }\end{array}$ & In vitro & 85 \\
\hline \multirow[t]{2}{*}{$\begin{array}{l}\text { EGCG } \\
\text { ECG }\end{array}$} & $\begin{array}{l}\text { Inducing apoptosis by activating caspases } 3,8 \text {, and } \\
9\end{array}$ & $\begin{array}{l}\text { In Isolated peripheral blood } \\
\text { monocytes }\end{array}$ & In vitro & 86 \\
\hline & $\begin{array}{l}\text { Downregulating CD11b expression } \\
\text { Attenuating adhesion and migration of peripheral } \\
\text { blood CD8+T cells }\end{array}$ & In peripheral blood $\mathrm{CD} 8+\mathrm{T}$ cells & In vitro & 87 \\
\hline \multirow[t]{3}{*}{ Resveratrol } & $\begin{array}{l}\text { Inhibiting stimulation of caspase- } 3 \text { and cleavage of } \\
\text { PARP induced by IL-1 } \beta\end{array}$ & In human articular chondrocytes & In vitro & 88 \\
\hline & $\begin{array}{l}\text { Suppressing the expression of iNOS mRNA and } \\
\text { protein by inhibiting the activation of NF- } \mathrm{KB} \\
\text { Inhibiting NO generation }\end{array}$ & In RAW 264.7 cells & In vitro & 89 \\
\hline & Upregulating MAP kinase phosphatase-5 & In prostate cells & In vitro & 90 \\
\hline \multirow[t]{2}{*}{ Apigenin } & $\begin{array}{l}\text { Blocking the expression of intercellular adhesion } \\
\text { molecule-1 (ICAM-1), VCAM-1, and E-selectin } \\
\text { Inhibiting prostaglandin synthesis and IL-6, } 8 \\
\text { production }\end{array}$ & In human endothelial cells & In vitro & 91 \\
\hline & $\begin{array}{l}\text { Inhibiting the upregulation of THP- } 1 \text { adhesion and } \\
\text { VCAM- } 1 \text { expression } \\
\text { Inhibiting the activity of the NF- } \kappa \mathrm{B}\end{array}$ & In HUVECs & In vitro & 92 \\
\hline Quercetin & $\begin{array}{l}\text { Inhibiting NO production and iNOS protein } \\
\text { expression }\end{array}$ & In NR8383 macrophages & In vitro & 93 \\
\hline $\begin{array}{l}\text { Anthocyanins } \\
\text { Hydroxy-cinnamic } \\
\text { acids }\end{array}$ & $\begin{array}{l}\text { Localizing into endothelial cells } \\
\text { Reducing the upregulation of IL-8, MCP-1, and } \\
\text { ICAM-1 }\end{array}$ & $\begin{array}{l}\text { In human microvascular } \\
\text { endothelial cells }\end{array}$ & In vitro & 94 \\
\hline \multirow[t]{3}{*}{ Curcumin } & $\begin{array}{l}\text { Decreasing MPO activity and TNF- } \alpha \text { on chronic } \\
\text { colitis } \\
\text { Reducing nitrites levels and the activation of p38 } \\
\text { MAPK } \\
\text { Downregulating COX-2 and iNOS expression }\end{array}$ & In rats & In vivo & 95 \\
\hline & Upregulating MAP kinase phosphatase-5 & In prostate cells & In vitro & 90 \\
\hline & $\begin{array}{l}\text { Suppressing the induction of COX-2 and iNOS } \\
\text { Inhibiting the expression of ICAM-1 and MCP-1 } \\
\text { Suppressing the Janus kinase (JAK)-STAT via } \\
\text { activation of Src homology } 2 \text { domain-containing } \\
\text { protein tyrosine phosphatases (SHP-2 ) }\end{array}$ & $\begin{array}{l}\text { In both rat primary microglia and } \\
\text { murine BV } 2 \text { microglial cells }\end{array}$ & In vitro & 97 \\
\hline
\end{tabular}

On the other hand, to counter the effects of oxidative stress, the cells also concomitantly express protective antioxidants such as glutamate cysteine ligase (GCL), manganese superoxide dismutase 
(MnSOD), and heme oxygenase-1(HO-1). In addition, expression of these antioxidant genes via modulation of MAPK-ARE-Nrf2 pathway is upregulated by EGCG and ECG in HepG2-ARE-C8 cell [10]. Apigenin, luteolin and quercetin had also been reported to inhibit inflammatory responses by downregulating the expression of iNOS and adhesion molecules in NR8383 macrophages and human endothelial cells [91-93].

\subsection{Antimutagenic/anticarcinogenic properties}

Dietary polyphenols could modulate diverse biochemical processes involved in carcinogenesis (Table 6). Curcumin exerted antitumor activities by inhibition of cellular proliferation and angiogenesis, blockade of tumor cell cycle progression, and induction of programmed cell death in vivo and in vitro $[109,110]$. Cellular signaling cascades mediated by NF- $\kappa$ B or AP-1 acted as a centerplay in regulating many of aforementioned biochemical processes [102,110].

Table 6. Antimutagenic/anticarcinogenic properties of dietary polyphenols.

\begin{tabular}{|c|c|c|c|c|}
\hline Dietary polyphenols & Protective effects and mechanisms & Conditions & Levels & Ref \\
\hline Hydroxytyrosol & $\begin{array}{l}\text { Inhibiting cell proliferation } \\
\text { Inducing apoptosis by arresting the cells in the G0/G1 } \\
\text { phase with a concomitant decrease in the cell } \\
\text { percentage in the } \mathrm{S} \text { and } \mathrm{G} 2 / \mathrm{M} \text { phases }\end{array}$ & $\begin{array}{l}\text { In human promyelocytic } \\
\text { leukaemia cells HL60 }\end{array}$ & In vitro & 98 \\
\hline \multirow{8}{*}{ Resveratrol } & $\begin{array}{l}\text { Inhibiting cell proliferation and downregulating } \\
\text { telomerase activity }\end{array}$ & In human colon tumor cells & In vitro & 99 \\
\hline & $\begin{array}{l}\text { Inducing apoptosis mediated by p53-dependent } \\
\text { pathway }\end{array}$ & In HepG2 cells & In vitro & 100 \\
\hline & $\begin{array}{l}\text { Inhibiting cell proliferation by interfering with an } \\
\text { estrogen receptor- } \alpha(E R \alpha) \text {-associated PI3K pathway }\end{array}$ & $\begin{array}{l}\text { In estrogen-responsive } \mathrm{MCF}-7 \\
\text { human breast cancer cells }\end{array}$ & In vitro & 101 \\
\hline & $\begin{array}{l}\text { Suppressing COX-2 expression by blocking the } \\
\text { activation of MAPKs and AP-1 }\end{array}$ & $\begin{array}{l}\text { In dorsal skin of female ICR } \\
\text { mice }\end{array}$ & In vitro & 102 \\
\hline & $\begin{array}{l}\text { Decreasing the expression of COX-1, COX-2, c-myc, } \\
\text { c-fos, c-jun, transforming growth factor-beta1 (TGF- } \\
\beta 1 \text { ) and TNF- } \alpha\end{array}$ & In mouse skin & Ex vivo & 50 \\
\hline & $\begin{array}{l}\text { Inhibiting oncogenic disease through the inhibition of } \\
\text { protein kinase CKII activity }\end{array}$ & In HeLa cell lysates & In vitro & 103 \\
\hline & $\begin{array}{l}\text { Inhibiting the } \mathrm{Ca}(2+) \text {-dependent activities of PKC } \alpha \\
\text { and PKC } \beta \mathrm{I}\end{array}$ & $\begin{array}{l}\text { On the activities of PKC } \\
\text { isozymes }\end{array}$ & In vitro & 104 \\
\hline & $\begin{array}{l}\text { Inhibiting nitrobenzene(NB)-DNA adducts and NB- } \\
\mathrm{Hb} \text { adducts }\end{array}$ & In male Kunming mice & In vivo & 105 \\
\hline Chlorogenic acid & Inhibiting the formation of DNA single strand breaks & In supercoiled pBR322 DNA & In vitro & 106 \\
\hline $\begin{array}{l}\text { Quercetin } \\
\text { Luteolin }\end{array}$ & Blocking EGFR tyrosine kinase activity & In MiaPaCa- 2 cancer cells & In vitro & 107 \\
\hline
\end{tabular}


Table 6. Cont.

\begin{tabular}{|c|c|c|c|c|}
\hline $\begin{array}{l}\text { Myricetin } \\
\text { Apigenin } \\
\text { Quercetin } \\
\text { Kaempferol }\end{array}$ & $\begin{array}{l}\text { Inhibiting human CYP1A1 activities } \\
\text { Inhibiting the formation of diolepoxide 2(DE2) and } \\
\mathrm{B}[\mathrm{a}] \mathrm{P} \text { activation }\end{array}$ & $\begin{array}{l}\text { On 7-ethoxyresorufin O- } \\
\text { deethylation }\end{array}$ & In vitro & 26 \\
\hline $\begin{array}{l}\text { Silymarin } \\
\text { Hesperetin } \\
\text { Quercetin } \\
\text { Daidzein }\end{array}$ & $\begin{array}{l}\text { Interacting with P-glycoprotein and modulating the } \\
\text { activity of ATP-binding cassette transporter, breast } \\
\text { cancer resistance protein (BCRP/ABCG2) }\end{array}$ & $\begin{array}{l}\text { In two separate BCRP- } \\
\text { overexpressing cell lines }\end{array}$ & In vitro & 108 \\
\hline EGCG & Inhibiting telomerase & $\begin{array}{l}\text { In human cancer cells } \\
\text { In nude mice models }\end{array}$ & $\begin{array}{l}\text { In vitro } \\
\text { In vivo }\end{array}$ & 114 \\
\hline \multirow[t]{4}{*}{ Curcumin } & $\begin{array}{l}\text { Suppressing proliferation and angiogenesis } \\
\text { Inhibiting NF-KB-regulated gene products (cyclin D1, c- } \\
\text { myc, Bcl-2, Bcl-xL, cellular inhibitor of apoptosis } \\
\text { protein-1, COX-2, MMP, and VEGF) }\end{array}$ & $\begin{array}{l}\text { In various pancreatic cancer cell } \\
\text { lines and nude mice }\end{array}$ & $\begin{array}{l}\text { In vitro } \\
\text { In vivo }\end{array}$ & 109 \\
\hline & $\begin{array}{l}\text { Inducing apoptosis by sustained phosphorylation of JNK } \\
\text { and p38 MAPK } \\
\text { Inhibitiing NF- } \mathrm{KB} \text { transcriptional activity } \\
\text { Inducing phosphorylation of c-jun and stimulation of AP- } \\
1 \text { transcriptional activity }\end{array}$ & In HCT116 cells & In vitro & 110 \\
\hline & $\begin{array}{l}\text { Inducing apoptosis through activation of caspase- } 8 \text {, BID } \\
\text { cleavage and cytochrome c release } \\
\text { Suppressing ectopic expression of Bcl- } 2 \text { and Bcl-xl }\end{array}$ & $\begin{array}{l}\text { In human acute myelogenous } \\
\text { leukemia HL- } 60 \text { cells }\end{array}$ & In vitro & 111 \\
\hline & $\begin{array}{l}\text { Inhibiting the Akt/mTOR/p70S6K pathway and } \\
\text { activating the ERK1/2 pathway } \\
\text { Inhibiting tumor growth and inducing autophagy }\end{array}$ & $\begin{array}{l}\text { In U87-MG and U373-MG } \\
\text { malignant glioma cells } \\
\text { In the subcutaneous xenograft } \\
\text { model of U87-MG cells }\end{array}$ & $\begin{array}{l}\text { In vitro } \\
\text { In vivo }\end{array}$ & 112 \\
\hline
\end{tabular}

Resveratrol could block the activation of MAPKs and AP-1 in the skin of mice [102]. Consumption of berries and red fruits rich in polyphenols contributed to the reduction of cancer through many mechanisms such as in vitro inhibiting human cytochrome P450-dependent monooxygenases 1A1 (CYP1A1) activities [26], blocking the epidermal growth factor receptor (EGFR) tyrosine kinase activity [107], and decreasing protein kinase CKII activity [103].

\subsection{Maintenance of gastrointestinal health and effects on digestive enzymes}

It had been reported that digestive enzymes such as lipase, $\alpha$-amylase, and $\alpha$-glucosidase, were inhibited by proanthocyanidins and tannins in young chicks, which decreased the digestibility of protein, starch and lipid [119, 120]. Resveratrol could inhibit pancreatic bile salt-dependent lipase (BSDL) activity, expression and secretion in the rat pancreatic AR4-2J cells [121]. Cyanidin-3 $\alpha-O-$ rhamnoside and quercetin-3 $\alpha-O$-rhamnoside could inhibit $\alpha$-glucosidase and advanced glycation end product (AGE) formation in vitro [123]. The inhibition of digestive enzymes by dietary polyphenols 
may represent an under-reported mechanism for delivering some of the health benefits attributed to a diet rich in fruit and vegetables.

\subsection{Modulation of signal transduction pathways}

Table 7. Effects of dietary polyphenols on signal transduction pathways.

\begin{tabular}{|c|c|c|c|c|}
\hline $\begin{array}{l}\text { Dietary } \\
\text { polyphenols }\end{array}$ & Protective effects and mechanisms & Conditions & Levels & Ref \\
\hline \multirow[t]{6}{*}{ Curcumin } & 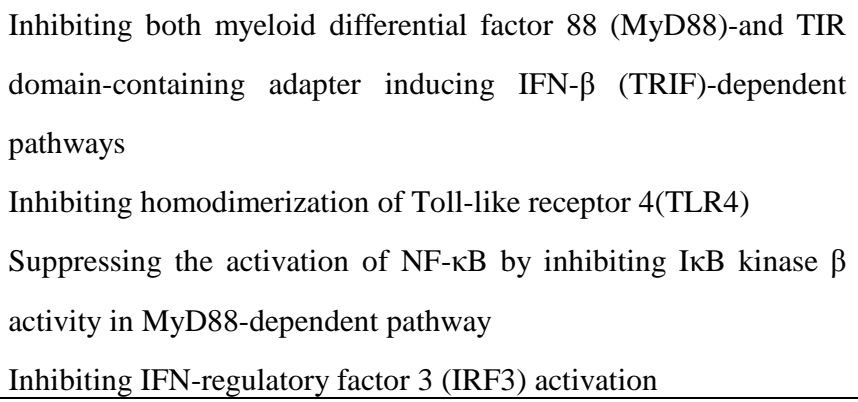 & In $293 \mathrm{~T}$ cells & In vitro & 124 \\
\hline & 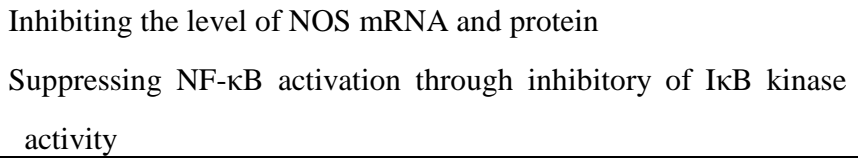 & In macrophages & In vitro & 125 \\
\hline & Suppressing COX-2 expression by inhibiting AP-1 and NF- $\mathrm{kB}$ & $\begin{array}{l}\text { In BV2 microglial } \\
\text { cells }\end{array}$ & In vitro & 126 \\
\hline & $\begin{array}{l}\text { Inhibiting IL-6-inducible STAT3 phosphorylation and nuclear } \\
\text { translocation }\end{array}$ & $\begin{array}{l}\text { In human multiple } \\
\text { myeloma cells }\end{array}$ & In vitro & 118 \\
\hline & $\begin{array}{l}\text { Upregulating CYP3A4 via pregnane X receptor (PXR) activation } \\
\text { Activating the electrophile responsive element (EpRE) of HO-1 } \\
\text { and enhancing the gastrointestinal (GI)-GPx activity }\end{array}$ & In HepG2 cells & In vitro & 127 \\
\hline & $\begin{array}{l}\text { Suppressing JAK-STAT inflammatory signaling through } \\
\text { activation of SHP-2 }\end{array}$ & $\begin{array}{l}\text { In both rat primary } \\
\text { microglia and murine } \\
\text { BV2 microglial cells }\end{array}$ & In vitro & 97 \\
\hline Proanthocyanidins & $\begin{array}{l}\text { Promoting apoptosis through alterations in Cdki-Cdk-cyclin } \\
\text { cascade, and caspase- } 3 \text { activation via loss of mitochondrial } \\
\text { membrane potential }\end{array}$ & $\begin{array}{l}\text { In human epidermoid } \\
\text { carcinoma A431 cells }\end{array}$ & In vitro & 128 \\
\hline Proanthocyanidins & 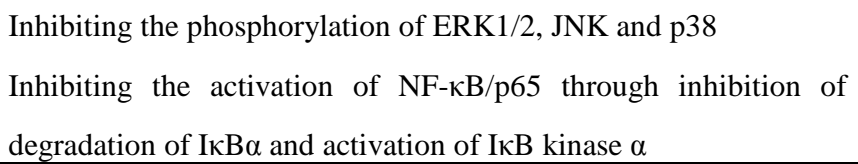 & $\begin{array}{l}\text { In SKH-1 hairless } \\
\text { mice }\end{array}$ & In vivo & 129 \\
\hline
\end{tabular}


Table 7. Effects

\begin{tabular}{|c|c|c|c|c|}
\hline Caffeic acid & $\begin{array}{l}\text { Modulating ceramide-induced signal transduction pathway and } \\
\mathrm{NF}-\kappa \mathrm{B} \text { activation } \\
\text { Inhibiting protein tyrosine kinase activity }\end{array}$ & In U937 cells & In vitro & 113 \\
\hline \multirow[t]{2}{*}{ Quercetin } & $\begin{array}{l}\text { Inhibiting phosphorylation of JNK and p38 MAPK on ROS- } \\
\text { mediated signaling }\end{array}$ & In HUVECs & In vitro & 117 \\
\hline & $\begin{array}{l}\text { Modulating } \mathrm{Akt} / \mathrm{PKB} \text { and ERK1/2 signalling cascades on } \\
\text { neuronal viability }\end{array}$ & $\begin{array}{l}\text { In primary cortical } \\
\text { neurons }\end{array}$ & $\begin{array}{l}\text { In vitro } \\
\text { In vivo }\end{array}$ & 130 \\
\hline Equol & $\begin{array}{l}\text { Mediating rapid vascular relaxation by Ca2+-independent } \\
\text { activation of eNOS/Hsp90 involving ERK1/2 and Akt } \\
\text { phosphorylation }\end{array}$ & $\begin{array}{l}\text { In human endothelial } \\
\text { cells }\end{array}$ & In vitro & 131 \\
\hline \multirow{3}{*}{ Resveratrol } & $\begin{array}{l}\text { Inhibiting monocyte CCR2 binding activity in an NO-, MAPK- } \\
\text { and PI3K-dependent manner } \\
\text { Inhibiting CCR } 2 \text { mRNA in an NO- and MAPK-independent, } \\
\text { PI3K-dependent manner }\end{array}$ & on THP-1 monocytes & In vitro & 58 \\
\hline & $\begin{array}{l}\text { Inhibiting proliferation of cardiac fibroblasts by NO-cGMP } \\
\text { signaling pathway }\end{array}$ & $\begin{array}{l}\text { In cultured rat cardiac } \\
\text { fibroblasts }\end{array}$ & In vitro & 59 \\
\hline & $\begin{array}{l}\text { Inducing phase II genes by regulating ARE/EpRE activation } \\
\text { Modifying the capability of Keap1 in sequestering Nrf2 }\end{array}$ & In PC12 cells & In vitro & 132 \\
\hline
\end{tabular}

Dietary polyphenols may not merely exert their diverse biological effects as free radical scavengers, but may also modulate cellular signaling processes by affecting signal transduction pathways [122] (Table 7). Studies have been reported that curcumin could in vitro modulate NF-кB activation [124], AP-1 DNA binding [126], signal transducer and activator of transcription-3 (STAT3) phosphorylation [118]. Resveratrol exerted protection in vitro through PI3-kinase/Akt pathway, MAPK proteins (ERK, JNK and P38) activation [58], and the translocation into the nucleus of Nrf2 [132]. Resveratrol could also upregulate the expressions of GCL, MnSOD, and HO-1 against oxidative stress via MAPK-ARENrf2 pathway in PC12 cells [132].

\subsection{Improvement of endothelium functions}

Several studies have indicated that red wine polyphenolic compounds (RWPCs) were able to inhibit proliferation and migration of vascular cells (Table 8). RWPCs induced nitric oxide (NO)mediated endothelium-dependent relaxations in isolated arteries. The activation of endothelial NO synthase (eNOS) was due to two distinct mechanisms: (a) an increase in $[\mathrm{Ca} 2+] \mathrm{i}$ and (b) a phosphorylation of eNOS by the PI3-kinase/Akt pathway [137]. In addition, RWPCs caused endothelium-derived hyperpolarizing factor (EDHF)-mediated relaxations of isolated arteries consecutively to a localized and controlled formation of superoxide anions leading to the activation of the PI3-kinase/Akt pathway [136]. RWPCs also increased endothelial prostacyclin release and inhibited the synthesis and the effects of endothelin- 1 in endothelial cell $[139,141]$. 
Table 8. Protective effects of dietary polyphenols on endothelial cells and blood vessels

\begin{tabular}{|c|c|c|c|c|}
\hline Dietary polyphenols & Protective effects and mechanisms & Conditions & Levels & Ref \\
\hline $\begin{array}{l}\text { EGCG } \\
\text { Quercetin }\end{array}$ & $\begin{array}{l}\text { Inhibiting apoptosis through modulation of Bcl-2 and Bax } \\
\text { Inhibiting nuclear transactivation of p53 } \\
\text { Decreasing the activity of caspase-3 } \\
\text { Blocking JNK- and p38 MAPK-related signaling }\end{array}$ & In HUVECs & In vitro & 117 \\
\hline \multirow{9}{*}{ RWPCs } & $\begin{array}{l}\text { Inhibiting the expression of VEGF mRNA and protein } \\
\text { Preventing the activation of the p } 38 \text { MAPK pathway }\end{array}$ & In VSMCs & In vitro & 133 \\
\hline & $\begin{array}{l}\text { Inhibiting the invasion and migration of VSMCs } \\
\text { Inhibiting pro-MMP-2 expression and its activation via } \\
\text { inhibition of membrane type 1-MMP (MT1-MMP) activity }\end{array}$ & In VSMCs & In vitro & 134 \\
\hline & $\begin{array}{l}\text { Inhibiting VSMCs migration through inhibiting the PI3K } \\
\text { activity and p38 MAPK phosphorylation } \\
\text { Inhibiting the phosphorylation of MKK } 3 / 6\end{array}$ & In cultured VSMCs & In vitro & 135 \\
\hline & $\begin{array}{l}\text { Inducing EDHF-mediated relaxations through activation of the } \\
\text { PI3-kinase/Akt pathway }\end{array}$ & $\begin{array}{l}\text { In porcine coronary } \\
\text { arteries }\end{array}$ & In vivo & 136 \\
\hline & $\begin{array}{l}\text { Increasing intracellular } \mathrm{Ca}^{2+} \text { and activate tyrosine kinases } \\
\text { Increasing NO production }\end{array}$ & $\begin{array}{l}\text { In bovine aortic } \\
\text { endothelial cells }\end{array}$ & In vitro & 137 \\
\hline & $\begin{array}{l}\text { Inhibiting NADPH oxidase activity and/or reducing endothelin- } \\
1(\text { ET-1) release }\end{array}$ & $\begin{array}{l}\text { In Twelve-week-old } \\
\text { male Wistar rats }\end{array}$ & In vivo & 138 \\
\hline & Inhibiting the synthesis of ET-1 & $\begin{array}{l}\text { In cultured bovine } \\
\text { aortic endothelial } \\
\text { cells }\end{array}$ & In vitro & 139 \\
\hline & Elevating NO and prostacyclin (PGI2) & In rats & In vivo & 140 \\
\hline & Ehancing PGI2 release & In endothelial cell & In vitro & 141 \\
\hline Cy3G & $\begin{array}{l}\text { Enhancing eNOS activity and expression } \\
\text { Inducing NO production } \\
\text { Regulating phosphorylation of eNOS and Akt Increasing cGMP } \\
\text { production }\end{array}$ & $\begin{array}{l}\text { In bovine vascular } \\
\text { endothelial cells }\end{array}$ & In vitro & 142 \\
\hline \multirow[t]{2}{*}{ EGCG } & $\begin{array}{l}\text { Having endothelial-dependent vasodilator actions } \\
\text { Activatiing phosphatidylinositol 3-kinase, Akt, and eNOS }\end{array}$ & $\begin{array}{l}\text { In bovine aortic } \\
\text { endothelial cells }\end{array}$ & In vitro & 143 \\
\hline & $\begin{array}{l}\text { Increasing eNOS activity } \\
\text { Inducing a sustained activation of Akt, ERK1/2, and eNOS } \\
\text { Ser1179 phosphorylation }\end{array}$ & $\begin{array}{l}\text { In bovine aortic } \\
\text { endothelial cells }\end{array}$ & In vitro & 144 \\
\hline Catechins & $\begin{array}{l}\text { Reducing the vascularization induced by the angiogenin-like } \\
\text { protein on chicken CAM }\end{array}$ & In chichen & In vitro & 145 \\
\hline Activin & Reducing ICAM-1, VCAM-1 and E-selectin & In systemic sclerosis & In vivo & 146 \\
\hline Proanthocyanidin & $\begin{array}{l}\text { Downregulating VCAM-1 expression; } \\
\text { Decreasing TNF } \alpha \text {-induced adherence of T-cells to HUVECs }\end{array}$ & In primary HUVECs & In vitro & 147 \\
\hline $\begin{array}{l}\text { Procyanidins Flavan- } \\
\text { 3-ols }\end{array}$ & Inhibiting angiotensin I converting enzyme (ACE) activity & In two substrates & In vitro & 148 \\
\hline
\end{tabular}


RWPCs could prevent matrix metalloproteinases-2 (MMP-2) activation and vascular endothelial growth factor (VEGF) expression in vascular smooth muscle cells (VSMCs) [133,134]. All these mechanisms might contribute to explain the vasodilatory, vasoprotective and anti-hypertensive effects of polyphenols in vivo.

Cyanidin-3-glucoside (Cy3G) and EGCG could enhance vascular eNOS activity and improve vascular endothelial function in bovine vascular endothelial cells [142]. Catechins had anti-angiogenic effects by reducing the vascularization on the chicken chorioallantoic membrane (CAM) [145].

\subsection{Protective effect on immune cell functions}

Dietary polyphenols appear to have a protective effect on immune cell functions. Alvarez et al. showed that leukocyte functions were improved in prematurely aging mice after five weeks of diet supplementation with polyphenol-rich cereals [149]. They could increase macrophage chemotaxis, phagocytosis, microbicidal activity, and natural killer function, and increase lymphoproliferation and IL-2 release in response to concanavalin A and lipopolysaccharide.

Curcumin could prevent tumor-induced $\mathrm{T}$ cell apoptosis by downregulating Bax level and augmenting Bcl-2 expression and restore cytokine-dependent Jak-3/Stat-5a signaling pathway in $\mathrm{T}$ cells of tumor bearer [150]. Caffeic acid, ellagic acid, and ferulic acid could inhibit apoptosis through the Bcl-2 independent mechanism in normal human peripheral blood mononuclear cells [116]. Thus, regular intake of these compounds will protect and improve quality of life.

\subsection{Antiallergic activity}

The incidence of type I allergic disorders have been increasing worldwide, particularly, the hypersensitivity to food. Akiyama and his coworkers reported that the apple condensed tannins intake would inhibit the development of the oral sensitization, and the inhibition could correlate with the rise in the population of TCR $\gamma \delta$-T cells in the intestinal intraepithelial lymphocytes [151]. Moreover, the apple condensed tannins could inhibit the release of histamine from rat basophilic leukemia (RBL2H3) cells stimulated by the antigen-stimulation and from rat peritoneal mast cells stimulated by compound 48/80. They also inhibited hyaluronidase activity and increase in intracellular free calcium concentration in RBL-2H3 cells stimulated with the antigen [152].

\subsection{Antidiabetic effects}

Johnston and coworkers demonstrated that glucose uptake into cells under sodium-dependent conditions was inhibited by flavonoid glycosides and non-glycosylated polyphenols in polarised Caco2 intestinal cells [154]. Under sodium-free conditions, aglycones and non-glycosylated polyphenols inhibited glucose uptake whereas glycosides and phenolic acids were ineffective. These data suggest that aglycones inhibit facilitated glucose uptake whereas glycosides inhibit the active transport of glucose. The non-glycosylated dietary polyphenols appeared to exert their effects via steric hindrance, while EGCG, ECG and (-)-epigallochatechin were effective against both transporters.

More recently, Koboyashi et al. have shown that the green tea polyphenols EGCG and ECG also inhibited glucose transport, possibly by sodium-dependent glucose transporter 1 (SGLT1) inhibition in 
the rabbit small intestine [155]. Song et al have presented evidence for quercetin-mediated inhibition of the facilitated diffusion glucose transporter 2 (GLUT2) in Chinese hamster ovary cells [156].

Anthocyanins inhibited $\alpha$-glucosidase activity and reduced blood glucose levels after starch-rich meals. This is a proven clinical therapy for controlling type II diabetes [158] (Table 9).

Table 9. Antidiabetic activity of dietary polyphenols.

\begin{tabular}{|c|c|c|c|c|}
\hline Dietary polyphenols & Protective effects and mechanisms & Conditions & Levels & Ref \\
\hline Curcumin & $\begin{array}{l}\text { Inhibiting diabetes-induced elevation in the } \\
\text { levels of IL-1 } \beta \text {, VEGF, and NF- } \kappa B \\
\text { Decreasing oxidatively modified DNA and } \\
\text { nitrotyrosine }\end{array}$ & In streptozotocin-induced diabetic rats & In vivo & 153 \\
\hline \multirow{2}{*}{$\begin{array}{l}\text { EGCG, ECG, (-)- } \\
\text { epigallochatechin }\end{array}$} & Inhibiting SGLT1 and sodium-free GLUT & In polarised Caco-2 intestinal cells & In vitro & 154 \\
\hline & Inhibiting SGLT1 and glucose uptake & In the rabbit small intestine & In vivo & 155 \\
\hline Quercetin & $\begin{array}{l}\text { Reducing blood glucose levels } \\
\text { Inhibiting sodium-dependent vitamin C } \\
\text { transporter } 1 \text { (SVCT1) and GLUT2 }\end{array}$ & In Chinese hamster ovary cells & In vitro & 156 \\
\hline Mangiferin & $\begin{array}{l}\text { Inhibiting sucrase, isomaltase, and aldose } \\
\text { reductase }\end{array}$ & In rats & In vivo & 157 \\
\hline Tannins Anthocyanin & Inhibiting $\alpha$-amylase and $\alpha$-glucosidase & $\begin{array}{l}\text { In the substrate of 2-chloro-4-nitro- } \\
\text { phenyl-4-O-b-D-galactopyranosyl- } \\
\text { maltoside }\end{array}$ & In vitro & 158 \\
\hline
\end{tabular}

\subsection{Regulation of cell cycle progression}

It was demonstrated that resveratrol and proanthocyanidins could regulate cell cycle progression by upregulating p21 expression, G1 phase arrest and downregulating cyclin D1/D2-Cdk6 in vitro [163$165,170]$ (Table 10).

\subsection{Modulation of hormonal effects and contraceptive activity}

Some studies showed that dietary polyphenols could modulate the level of hormone. Resveratrol could exert mixed estrogen agonist/antagonist activities in mammary tumor models. It could affect the expression of $17 \beta$-estradiol-responsive progesterone receptor $(\mathrm{PR})$ and presnelin 2 proteins in vitro and in vivo [159]. Bhat et al. showed that resveratrol exhibited antiestrogenic properties and inhibited the levels and activity of PR by downregulating $\alpha$ (1)-integrin expression in human endometrial adenocarcinoma cells [160].

Otake and his coworkers demonstrated that quercetin and resveratrol potently reduced estrogen sulfotransferase (EST) activity and inhibited sulfation of $17 \beta$-estradiol in normal human mammary epithelial cells [161]. Both of the compounds potently inhibited recombinant human EST. In fact, they could serve as substrates for EST. Gossypol, a polyphenolic compound from cotton seed, had contraceptive activity and could inhibit $11 \beta$-hydroxysteroid dehydrogenase and cause hypokalemia in some men [162]. 
Table 10. Regulate cell cycle progression of dietary polyphenols.

\begin{tabular}{|c|c|c|c|c|}
\hline $\begin{array}{l}\text { Dietary } \\
\text { polyphenols }\end{array}$ & Protective effects and mechanisms & Conditions & Levels & Ref \\
\hline \multirow{7}{*}{ Resveratrol } & $\begin{array}{l}\text { Upregulating p21 expression and cause G1 phase } \\
\text { arrest }\end{array}$ & In HepG2 cells & In vitro & 163 \\
\hline & $\begin{array}{l}\text { Inhibiting cyclin D1/D2-cdk6, cyclin D1/D2- } \\
\text { cdk4, and cyclin E-cdk2 complexes }\end{array}$ & $\begin{array}{l}\text { In human epidermoid carcinoma } \\
\text { A431 cells }\end{array}$ & In vitro & 164 \\
\hline & $\begin{array}{l}\text { Downregulatiing cyclin D1/Cdk4 complex and } \\
\text { Upregulating cyclin E and A expression }\end{array}$ & $\begin{array}{l}\text { In the human colonic adenocarcinoma } \\
\text { cell line Caco-2 }\end{array}$ & In vitro & 165 \\
\hline & $\begin{array}{l}\text { Decreasing in the hyperphosphorylated form of } \\
\mathrm{pRb} \text { and increasing in hypophosphorylated } \mathrm{pRb} \\
\text { Downregulating the protein expression of E2F (1- } \\
\text { 5) family members of transcription factors and } \\
\text { their heterodimeric partners DP1 and DP2 } \\
\text { Leading to a G0/G1 arrest }\end{array}$ & $\begin{array}{l}\text { In human epidermoid carcinoma } \\
\text { A431 cells }\end{array}$ & In vitro & 166 \\
\hline & $\begin{array}{l}\text { Inhibiting the expression of cyclin B1, D1, A1 } \\
\text { and } \beta \text {-catenin }\end{array}$ & $\begin{array}{l}\text { In six human cancer cell lines } \\
\text { (MCF7, SW480, HCE7, Seg-1, Bic-1, } \\
\text { and HL60) }\end{array}$ & In vitro & 167 \\
\hline & Arresting cell cycle in the G1-S phase & In VSMCs & In vitro & 168 \\
\hline & $\begin{array}{l}\text { Upregulating the expression of cyclins A, E, and } \\
\text { B1 }\end{array}$ & In human SK-Mel-28 melanoma cells & In vitro & 169 \\
\hline Proanthocyanidins & $\begin{array}{l}\text { Increasing G1-phase arrest } \\
\text { Inhibiting cyclin-dependent kinases (Cdk) Cdk2, } \\
\text { Cdk4, Cdk6 and cyclins D1, D2 and E } \\
\text { Increasing the protein expression of cyclin- } \\
\text { dependent kinase inhibitors (Cdki), Cip1/p21 and } \\
\text { Kip1/p27 } \\
\text { Enhancing the binding of Cdki-Cdk }\end{array}$ & $\begin{array}{l}\text { In human epidermoid carcinoma } \\
\text { A431 cells }\end{array}$ & In vitro & 170 \\
\hline
\end{tabular}

\subsection{Effect in the treatment of chronic obstructive pulmonary disease (COPD)}

Since a variety of oxidants and free radicals are implicated in the pathogenesis of COPD, it is possible that therapeutic administration of multiple antioxidants will be effective in the treatment of COPD. Various approaches to enhance lung antioxidant capacity and clinical trials of dietary polyphenols in COPD are discussed. Resveratrol, EGCG, and quercetin could inhibit inflammatory gene expression by controling NF- $\kappa \mathrm{B}$ activation and regulate GSH biosynthesis and chromatin remodel in human airway epithelial A549 cells $[171,172]$. Curcumin could decrease protein/mRNA expressions of pulmonary type I collagen (Col-I) and TGF- $\beta 1$ in rats [173]. 


\subsection{Other bioactive effects}

It has been demonstrated that dietary polyphenols have other bioactive effects (Table 11), such as antibacterial activity of Gnemonol B and gnetin E [174], anti-HIV effect of proanthocyanidins [176], hepatoprotective ability of a novel proanthocyanidins IH636 [178], and angiogenesis effect of proanthocyanidins [177].

Table 11. Other bioactive effects of dietary polyphenols.

\begin{tabular}{|c|c|c|c|c|c|}
\hline $\begin{array}{l}\text { Type of } \\
\text { Activity }\end{array}$ & $\begin{array}{l}\text { Dietary } \\
\text { polyphenols }\end{array}$ & Protective effects and mechanisms & Conditions & Levels & Ref \\
\hline \multirow[t]{2}{*}{$\begin{array}{l}\text { Antibacterial } \\
\text { activity }\end{array}$} & $\begin{array}{l}\text { Gnemonol } \mathrm{B} \text { and } \\
\text { gnetin } \mathrm{E}\end{array}$ & $\begin{array}{l}\text { Exhibiting strong antibacterial activities against } \\
\text { vancomycin-resistant Enterococci (VRE) and } \\
\text { methicillin-resistant Staphylococcus aureus } \\
\text { (MRSA) }\end{array}$ & $\begin{array}{l}\text { In Enterococci and } \\
\text { Staphylococcus aureus }\end{array}$ & In vitro & 174 \\
\hline & Hydroxytyrosol & $\begin{array}{l}\text { Antimycoplasmal activity against } \mathrm{M} \text {. } \\
\text { pneumoniae, M. hominis, and } M \text {. fermentans }\end{array}$ & In Mycoplasma & In vitro & 175 \\
\hline $\begin{array}{l}\text { Anti-HIV } \\
\text { effects }\end{array}$ & $\begin{array}{l}\text { Proanthocyanidin } \\
\text { s }\end{array}$ & $\begin{array}{l}\text { Downregulating the expression of the HIV-1 } \\
\text { entry co-receptors, CCR } 2 b, C C R 3 \text { and CCR5 }\end{array}$ & $\begin{array}{l}\text { In normal peripheral } \\
\text { blood mononuclear } \\
\text { cells }\end{array}$ & In vitro & 176 \\
\hline $\begin{array}{l}\text { Angiogenesis } \\
\text { effect }\end{array}$ & $\begin{array}{l}\text { Proanthocyanidin } \\
\mathrm{s} \\
\text { Resveratrol }\end{array}$ & Upregulating VEGF expression & $\begin{array}{l}\text { In cultured } \\
\text { keratinocytes }\end{array}$ & In vitro & 177 \\
\hline \multirow[t]{3}{*}{$\begin{array}{l}\text { Hepato- } \\
\text { protective } \\
\text { ability }\end{array}$} & $\begin{array}{l}\text { A novel } \\
\text { Proanthocyanidin } \\
\text { s IH636 }\end{array}$ & $\begin{array}{l}\text { Increasing the expression of Bcl-xL } \\
\text { Attenuating acetaminophen-induced hepatic } \\
\text { DNA damage, apoptotic and necrotic cell death } \\
\text { of liver cells }\end{array}$ & In male ICR mice & In vivo & 178 \\
\hline & Daidzein & $\begin{array}{l}\text { Ameliorating the d-galactosamine-induced } \\
\text { increase in malondialdehyde-protein adducts and } \\
\text { cytosolic SOD activities }\end{array}$ & In the rat liver & In vivo & 179 \\
\hline & Genistein & $\begin{array}{l}\text { Reducing experimental liver damage caused by } \\
\mathrm{CCl}(4) \text { by preventing lipid peroxidation and } \\
\text { strengthening antioxidant systems }\end{array}$ & In rats & In vitro & 180 \\
\hline
\end{tabular}

\section{Prooxidant activity and cellular effects of the phenoxyl radicals of dietary polyphenols}

Dietary polyphenols have beneficial antioxidant, anti-inflammatory and anticancer effects. However, at higher doses or under certain conditions these compounds may exert toxic prooxidant activities [181]. Galati et al. [182] have observed that dietary polyphenols with phenol rings were metabolized by peroxidase to form prooxidant phenoxyl radicals which, in some cases were sufficiently reactive to cooxidize GSH or NADH accompanied by extensive oxygen uptake and reactive oxygen species formation. Polyphenols with catechol rings also cooxidized ascorbate, likely mediated by semiquinone radicals. Incubation of hepatocytes with dietary polyphenols containing 
phenol rings was found to partially oxidize hepatocyte GSH to GSSG while polyphenols with a catechol ring were found to deplete GSH through formation of GSH conjugates.

Dietary polyphenols with phenol rings also oxidized human erythrocyte oxyhemoglobin and caused erythrocyte hemolysis more readily than polyphenols with catechol rings. It is concluded that polyphenols containing a phenol ring are generally more prooxidant than polyphenols containing a catechol ring. Subsequent studies revealed that [183] B-ring catechol-type flavonoids showed swift formation of their two electron oxidized quinone type metabolites, even upon their one electron oxidation by peroxidases. Enzymatic and/or chemical (auto) oxidation of the flavonoid generates the flavonoid semiquinone radical, which may be scavenged by GSH, thereby regenerating the flavonoid and generating the thiyl radical of glutathione. This thiyl radical may react with GSH to generate a disulfide radical anion which rapidly reduces molecular oxygen to superoxide anion radicals.

Huisman et al. [184] found that wine polyphenols and ethanol do not significantly scavenge superoxide nor affect endothelial nitric oxide production. Studies showed that flavonoids can induce oxidative damage and nick DNA via the production of radicals in the presence of $\mathrm{Cu}$ and $\mathrm{O}(2)$. Al, $\mathrm{Zn}$, $\mathrm{Ca}, \mathrm{Mg}$ and $\mathrm{Cd}$ have been found to stimulate phenoxyl radical-induced lipid peroxidation [185]. As a result of such enzymatic as well as non-enzymatic antioxidant reactions, phenoxyl radicals are formed as the primary oxidized products. Phenoxyl radicals can initiate lipid peroxidation. It is concluded that the prooxidant cytotoxicity of diet polyphenols is due to formation of ROS [186], role of phenoxyl radical/phenol redox couple [187], and stimulation by metals [185].

\section{Bioavailability of dietary polyphenols}

Polyphenols are the most abundant antioxidants in the human diet. They show a considerable structural diversity, which largely influences their bioavailability [188]. The biological properties of polyphenols depend on the amount consumed and on their bioavailability. Bioavailability appears to differ greatly between the various polyphenols, and the most abundant polyphenols in our diet are not necessarily those leading to the highest concentrations of active metabolites in target tissues [189]. Both isoflavones and phenolic acids like caffeic acid and gallic acid are the most well absorbed polyphenols, followed by catechins, flavanones, and quercetin glucosides, but with different kinetics. The least well-absorbed polyphenols are large molecular weight polyphenols such as the proanthocyanidins, the galloylated tea catechins, and the anthocyanins [190].

Ellagic acid was detected in human plasma at a maximum concentration $(31.9 \mathrm{ng} / \mathrm{mL})$ after $1 \mathrm{~h}$ postingestion [191]. Absorption of flavanols such as catechins was enhanced when tea polyphenols were administered as a green tea supplement in capsule form when consumed in the absence of food and led to a small but significant increase in plasma antioxidant activity compared with when tea polyphenols were consumed as black tea or green tea $[192,193]$. No differences were found in plasma EGCG concentrations and trolox equivalents determined by the trolox equivalent antioxidant capacity assay after administration as a single large dose in the form of either purified EGCG or as green tea extract (Polyphenon E) [194]. Hydroxytyrosol, the major olive oil phenolic compound, is dosedependently absorbed from olive oil [195]. Tuck et al. showed that hydroxytyrosol intravenously and orally administered oil-based dosings resulted in significantly greater elimination of the phenolics in urine within $24 \mathrm{~h}$ than the oral, aqueous dosing method. Oral bioavailability estimates of hydroxyl- 
tyrosol when administered in an olive oil solution and when dosed as an aqueous solution was $99 \%$ and $75 \%$, respectively [13].

Once absorbed, polyphenols are conjugated to glucuronide, sulphate and methyl groups in the gut mucosa and inner tissues. Non-conjugated polyphenols are virtually absent in plasma. Such reactions facilitate their excretion and limit their potential toxicity. EGCG and ECG were present in plasma mostly as the free form, whereas epicatechin and epigallocatechin were mostly present as the glucuronide and sulfate conjugates [192]. Recent data suggest that beta-glucosidases and maybe also lactase phlorizin hydrolase (LPH) in the small intestine are capable of hydrolysing flavonoid glucosides and these compounds are thus taken up as the free aglycon and not as the intact glycosides [196]. It has been reported that around $98 \%$ of hydroxytyrosol is present in plasma and urine in conjugated forms, mainly glucuronoconjugates, suggesting an extensive first pass intestinal/ hepatic metabolism of the ingested primary forms [197-199] and the 3-O-glucuronide of hydroxytyrosol shows stronger activity as a radical scavenger than hydroxytyrosol itself [200]. The major metabolites identified in in vitro and in vivo studies were an Omethylated derivative of hydroxytyrosol, glucuronides of hydroxytyrosol and a novel glutathionyl conjugate of hydroxytyrosol [200,201]. It has been recently reported that hydroxytyrosol and its metabolites are capable of binding human LDL after olive oil ingestion [202].

The polyphenols reaching the colon are extensively metabolised by the microflora into a wide array of low molecular weight phenolic acids. It has been shown that the plasma concentrations of total metabolites ranged from 0 to $4 \mu \mathrm{mol} / \mathrm{L}$ with an intake of $50 \mathrm{mg}$ aglycone equivalents, and the relative urinary excretion ranged from $0.3 \%$ to $43 \%$ of the ingested dose, depending on the polyphenol [189]. The biological properties of both conjugated derivatives and microbial metabolites will be essential to better assess the health effects of dietary polyphenols. Alternatively, some health effects of polyphenols may not require their absorption through the gut barrier. Their role as iron chelators in the gut lumen is briefly discussed. Tannic acid and catechin both interact with the gut but only catechin appears able to traverse the gut. In addition, they provide evidence for binding of tannic acid and catechin by endogenous proteins in the intestinal lumen. This may limit their absorption from the small intestine [203].

\section{Conclusions}

Consumption of polyphenol-rich fruits, vegetables, and beverages derived from plants, such as cocoa, red wine and tea, represents a diet beneficial to human health. Some dietary polyphenols possess antioxidative and anti-inflammatory properties, to some extent, contributing to their cancer chemopreventive potential. These phenolic substances have the ability to abrogate various biochemical processes induced or mediated by the tumor promoters. Some dietary polyphenols also induce apoptosis in premalignant or cancerous cells, and suppress growth and proliferation of various types of tumor cells via induction of apoptosis or arrest of a specific phase of the cell cycle.

However, the specific mechanism(s) by which these compounds affect human health remains unclear, despite extensive research conducted in this area in recent years. Most of that research has focused on the antioxidant properties of dietary polyphenols, which are well characterized and well established in vitro. The in vitro data often conflict with results obtained from in vivo studies on the antioxidant capacity of plasma or the resistance of plasma and lipoproteins to oxidation ex vivo after the consumption of polyphenols-rich foods by human subjects. These inconsistencies between the in 
vitro and the in vivo data are likely explained by the limited bioavailability of dietary polyphenols and their extensive metabolism in humans. Most of them exert multifacet action, and any clinical applications using these substances should be based on the precise understanding of the physiologically relevant action mechanisms.

\section{Acknowledgements}

This project was supported by a grant from the National Natural Science Foundation of P.R.China (No. 30472072)

\section{References}

1. Gutteridge, J.M. Free radicals in diseases processes: a compilation of cause and consequence. Free Radic. Res. Commun. 1993, 19, 141-158.

2. Kehrer, J.P. Free radicals as mediators of tissue injury and disease. Crit. Rev. Toxicol. 1993, 23, 21- 48.

3. Becker, L.B. New concepts in reactive oxygen species and cardiovascular reperfusion physiology. Cardiovasc. Res. 2004, 61, 461-470.

4. Hayes, J.D.; McLellan, L.I. Glutathione and glutathione-dependent enzymes represent a coordinately regulated defences against oxidative stress. Free Radic. Res. 1999, 31, 273-300.

5. Masella, R.; Di Benedetto, R.; Vari, R.; Filesi, C.; Giovannini, C. Novel mechanisms of natural antioxidant compounds in biological systems: involvement of glutathione and glutathione-related enzymes. J. Nutr. Biochem. 2005, 16, 577-586.

6. Hartman, R.E.; Shah, A.; Fagan, A.M.; Schwetye, K.E.; Parsadanian, M.; Schulman, R. N.; Beth Finn, M.; Holtzman, D.M. Pomegranate juice decreases amyloid load and improves behavior in a mouse model of Alzheimer's disease. Neurobiol. Dis. 2006, 24, 506-515.

7. Hollman, P.C.; van Trijp, J.M.; Buysman, M.N.; van der Gaag, M.S.; Mengelers, M.J.; de Vries, J.H.; Katan, M.B. Relative bioavailability of the antioxidant flavonoid quercetin from various foods in man. FEBS Lett. 1997, 418, 152-156.

8. Shen, S,Q.; Zhang, Y.; Xiang, J.J.; Xiong, C.L. Protective effect of curcumin against liver warm ischemia/reperfusion injury in rat model is associated with regulation of heat shock protein and antioxidant enzymes. World J. Gastroenterol. 2007, 13, 1953-1961.

9. Molina, M.F.; Sanchez-Reus, I.; Iglesias, I.; Benedi, J. Quercetin, a flavonoid antioxidant, prevents and protects against ethanol-induced oxidative stress in mouse liver. Biol. Pharm. Bull. 2003, 26, 1398-1402.

10. Chen, C.; Yu, R.; Owuor, E.D.; Kong, A.N. Activation of antioxidant response element (ARE), mitogen-activated protein kinases (MAPKs) and caspases by major green tea polyphenol components during cell survival and death. Arch. Pharm. Res. 2000, 23, 605-612.

11. Butterfield, D.A.; Castegna, A.; Pocernich, C. B.; Drake, J.; Scapagninib, G.; Calabresec, V. Nutritional approaches to combat oxidative stress in Alzheimer's disease. J. Nutr. Biochem. 2002, 13, 444-461.

12. Schaffer, S.; Podstawa, M.; Visioli, F.; Bogani, P.; Müller, W.E.; Eckert, G.P. Hydroxytyrosolrich olive mill wastewater extract protects brain cells in vitro and ex vivo. J. Agric. Food Chem. 2007, 55, 5043-5049. 
13. Tuck, K.L.; Freeman, M.P.; Hayball, P.J.; Stretch, G.L.; Stupans, I. The in vivo fate of hydroxytyrosol and tyrosol, antioxidant phenolic constituents of olive oil, after intravenous and oral dosing of labeled compounds to rats. J. Nutr. 2001, 131, 1993-1996.

14. Rice-Evans, C.A.; Mmiller, N.J.; and Paganga, G. Antioxidant properties of phenolic compounas. Trends Plant Sci. 1997, 2, 152-159.

15. Nielsen, I.L.; Dragsted, L.O.; Ravn-Haren, G.; Freese, R.; Rasmussen, S.E. Absorption and excretion of black currant anthocyanins in humans and watanabe heritable hyperlipidemic rabbits. J. Agric. Food Chem. 2003, 51, 2813-2820.

16. Bub, A.; Watzl, B.; Heeb, D.; Rechkemmer, G.; Briviba, K. Malvidin-3-glucoside bioavailability in humans after ingestion of red wine, dealcoholized red wine and red grape juice. Eur. J. Nutr. 2001, 40, 113-120.

17. McAnlis, G.T.; McEneny, J.; Pearce, J.; Young, I.S. Absorption and antioxidant effects of quercetin from onions, in man. Eur. J. Clin. Nutr. 1999, 53, 92-96.

18. Manach, C.; Morand, C.; Gil-Izquierdo, A.; Bouteloup-Demange, C.; Remesy, C. Bioavailability in humans of the flavanones hesperidin and narirutin after the ingestion of two doses of orange juice. Eur. J. Clin. Nutr. 2003, 57, 235-242.

19. Lotito, S.B.; Frei, B. Consumption of flavonoid-rich foods and increased plasma antioxidant capacity in humans: Cause, consequence, or epiphenomenon? Free Radic. Biol. Med. 2006, 41, 1727-1746.

20. Erlund, I.; Meririnne, E.; Alfthan, G.; Aro, A. Plasma kinetics and urinary excretion of the flavanones naringenin and hesperetin in humans after ingestion of orange juice and grapefruit juice. J. Nutr. 2001, 131,235-241.

21. Henning, S.M.; Niu, Y.; Liu, Y.; Lee, N.H.; Hara, Y.; Thames, G.D.; Minutti, R.R.; Carpenter, C.L.; Wang, H.; Heber, D. Bioavailability and antioxidant effect of epigallocatechin gallate administered in purified form versus as green tea extract in healthy individuals. J. Nutr. Biochem. 2005, 16, 610-616.

22. Widlansky, M.E.; Duffy, S.J.; Hamburg, N.M.; Gokce, N.; Warden, B.A.; Wiseman, S.; Keaney, Jr., J.F.; Frei, B.; Vita, J.A. Effects of black tea consumption on plasma catechins and markers of oxidative stress and inflammation in patients with coronary artery disease. Free Radic. Biol. Med. 2005, 38, 499-506.

23. Bell, J.R.; Donovan, J.L.; Wong, R.; Waterhouse, A.L.; German, J.B.; Walzem, R. L.; KasimKarakas, S.E. (+)-Catechin in human plasma after ingestion of a single serving of reconstituted red wine. Am. J. Clin. Nutr. 2000, 71, 103-108.

24. Holt, R.R.; Lazarus, S.A.; Sullards, M.C.; Zhu, Q.Y.; Schramm, D.D.; Hammerstone, J.F.; Fraga, C.G.; Schmitz, H.H.; Keen, C.L. Procyanidin dimer B2 [epicatechin-(4beta-8)-epicatechin] in human plasma after the consumption of a flavanol-rich cocoa. Am. J. Clin. Nutr. 2002, 76, 798804.

25. Lotito, S.B.; Frei, B. Consumption of flavonoid-rich foods and increased plasma antioxidant capacity in humans: Cause, consequence, or epiphenomenon? Free Radic. Biol. Med. 2006, 41, 1727-1746. 
26. Schwarz, D. and Roots, I. In vitro assessment of inhibition by natural polyphenols of metabolic activation of procarcinogens by human CYP1A1. Biochem. Biophys. Res. Commun. 2003, 303, 902-907.

27. Gonthier, M.P.; Remesy, C.; Scalbert, A.; Cheynier,V.; Souquet, J.M.; Poutanen, K.; Aura, A.M. Microbial metabolism of caffeic acid and its esters chlorogenic and caftaric acids by human faecal microbiota in vitro. Biomed. Pharmacother. 2006, 60, 536-540.

28. Seeram, N. P.; Lee, R.; Heber, D. Bioavailability of ellagic acid in human plasma after consumption of ellagitannins from pomegranate (Punica granatum L.) juice. Clin. Chim. Acta 2004, 348, 63-68.

29. Rangkadilok, N.; Sitthimonchai, S.; Worasuttayangkurn, L.; Mahidol, C.; Ruchirawat, M.; Satayavivad, J. Evaluation of free radical scavenging and antityrosinase activities of standardized longan fruit extract. Food Chem. Toxicol. 2007, 45, 328-336.

30. Ray, P.S.; Maulik, G.; Cordis, G.A.; Bertelli, A.A.; Bertelli, A.; Das, D.K. The red wine antioxidant resveratrol protects isolated rat hearts from ischemia reperfusion injury. Free Radic. Biol. Med. 1999, 27, 160-169.

31. Zhang, Y.; Liu, Y.; Wang, T.; Li, B.; Li, H.; Wang, Z.; Yang, B. Resveratrol, a natural ingredient of grape skin:Antiarrhythmic efficacy and ionic mechanisms. Biochem. Biophys. Res. Commun. 2006, 340, 1192-1199.

32. Chung KT, Wong TY, Wei CI, Huang YW, Lin Y. Tannins and human health: a review. Crit. Rev. Food Sci. Nutr. 1998, 38, 421-464.

33. Sharma, R.A.; Gescher, A.J.; Steward, W.P. Curcumin: The story so far. Eur. J. Cancer 2005, 41, 1955-1968.

34. Hong, J.; Smith, T.J.; Ho, C.T.; August, D.A.; Yang, C.S. Effects of purified green and black tea polyphenols on cyclooxygenase- and lipoxygenase-dependent metabolism of arachidonic acid in human colon mucosa and colon tumor tissues. Biochem. Pharmacol. 2001, 62, 1175-1183.

35. Fki, I.; Sahnoun, Z.; Sayadi, S. Hypocholesterolemic effects of phenolic extracts and purified hydroxytyrosol recovered from olive mill wastewater in rats fed a cholesterol-rich diet. J. Agric. Food Chem. 2007, 55, 624-631.

36. Kohyama, N.; Nagata, T.; Fujimoto, S.; Sekiya, K. Inhibition of arachidonate lipoxygenase activities by 2-(3, 4-dihydroxyphenyl) ethanol, a phenolic compound from olives. Biosci. Biotechnol. Biochem. 1997, 61, 347-350.

37. Du, Y.; Guo, H.; Lou, H. Grape seed polyphenols protect cardiac cells from apoptosis via induction of endogenous antioxidant enzymes. J. Agric. Food Chem. 2007, 55, 1695-1701.

38. Appiah-Opong, R.; Commandeur, J.N.; van Vugt-Lussenburg, B.; Vermeulen, N.P. Inhibition of human recombinant cytochrome P450s by curcumin and curcumin decomposition products. Toxicology 2007, 235, 83-91.

39. Zheng, J.; Ramirez, V.D. Inhibition of mitochondrial proton F0F1-ATPase/ATP synthase by polyphenolic phytochemicals. Br. J. Pharmacol. 2000, 130, 1115-1123.

40. Nishinaka, T.; Ichijo, Y.; Ito, M.; Kimura, M.; Katsuyama, M.; Iwata, K.; Miura, T.; Terada, T.; Yabe-Nishimura, C. Curcumin activates human glutathione S-transferase P1 expression through antioxidant response element. Toxicol Lett. 2007, 170, 238-247. 
41. Gil, B.; Sanz, M.J.; Terencio, M.C.; Ferrandiz, M.L.; Bustos, G.; Paya M, Gunasegaran, R.; Alcaraz, M.J. Effects of flavonoids on Naja naja and human recombinant synovial phospholipase A2 and inflammatory responses in mice. Life Sci. 1994, 54, 333-338.

42. Huang, J.; de Paulis, T.; May, J.M. Antioxidant effects of dihydrocaffeic acid in human EA.hy926 endothelial cells. J. Nutr. Biochem. 2004, 15, 722-729.

43. Kerry, N.; Rice-Evans, C. Inhibition of peroxynitrite-mediated oxidation of dopamine by flavonoid and phenolic antioxidants and their structural relationship. J. Neurochem. 1999, 73, 247-253.

44. Alía, M.; Ramos, S.; Mateos, R.; Granado-Serrano, A.B.; Bravo, L.; Goya, L. Quercetin protects human hepatoma HepG2 against oxidative stress induced by tert-butyl hydroperoxide. Toxicol. Appl. Pharmacol. 2006, 212, 110-118.

45. Valerio, L.G.; Jr.; Kepa, J.K.; Pickwell, G.V.; Quattrochi, L.C. Induction of human NAD(P)H:quinone oxidoreductase (NQO1) gene expression by the flavonol quercetin. Toxicol. Lett. 2001, 119, 49-57.

46. Motohashi, H.; Yamamoto, M. Nrf2-Keap1 defines a physiologically important stress response mechanism. Trends Mol. Med. 2004, 10, 549-557.

47. Scharf, G,; Prustomersky, S.; Knasmuller, S.; Schulte-Hermann, R.; Huber, W.W. Enhancement of glutathione and g-glutamylcysteine synthetase, the rate limiting enzyme of glutathione synthesis, by chemoprotective plant-derived food and beverage components in the human hepatoma cell line HepG2. Nutr. Cancer 2003, 45, 74-83.

48. Tanigawa, S.; Fujii, M.; Hou, D.X. Action of Nrf2 and Keap1 in ARE-mediated NQO1 expression by quercetin. Free Radic. Biol. Med. 2007, 42, 1690-1703.

49. Cadenas, S.; Barja, G. Resveratrol, melatonin, vitamin E, and PBN protect against renal oxidative DNA damage induced by the kidney carcinogen KBrO3. Free Radic. Biol. Med. 1999, 26, 15311537.

50. Jang, M.; Pezzuto, J.M. Effects of resveratrol on 12-O-tetradecanoylphorbol -13-acetate -induced oxidative events and gene expression in mouse skin. Cancer Lett. 1998, 134, 81-89.

51. Dubuisson, J.G.; Dyess, D.L.; Gaubatz, J.W. Resveratrol modulates human mammary epithelial cell O-acetyltransferase, sulfotransferase, and kinase activation of the heterocyclic amine carcinogen N-hydroxy-PhIP. Cancer Lett. 2002, 182, 27-32.

52. Ciolino, H.P.; Yeh, G.C. Inhibition of aryl hydrocarbon induced cytochrome P-4501A1 enzyme activity and CYP1A1 expression by resveratrol. Mol. Pharmacol. 1999, 56, 760-767.

53. Casper, R.F.; Quesne, M.; Rogers, I.M.; Shirota, T.; Jolivet, A.; Milgrom, E.; Savouret, J.F. Resveratrol has antagonist activity on the aryl hydrocarbon receptor: implications for prevention of dioxin toxicity. Mol. Pharmacol. 1999, 56, 784-790.

54. Schewe, T.; Sadik, C.; Klotz, L.O.; Yoshimoto, T.; Kuhn, H.; Sies, H. Polyphenols of cocoa: inhibition of mammalian 15-lipoxygenase. Biol. Chem. 2001, 382, 1687-1696.

55. Subbaramaiah, K.; Chung, W.J.; Michaluart, P.; Telang, N.; Tanabe, T.; Inoue, H.; Jang, M.; Pezzuto, J.M.; Dannenberg, A.J. Resveratrol inhibits cyclooxygenase-2 transcription and activity in phorbol ester-treated human mammary epithelial cells. J. Biol. Chem. 1998, 273, 21875-21882.

56. Li, Y.T.; Shen, F.; Liu, B.H.; Cheng, G.F. Resveratrol inhibits matrix metalloproteinase-9 transcription in U937 cells. Acta Pharmacol. Sin. 2003, 24, 1167-1171. 
57. Kaga, S.; Zhan, L.; Matsumoto, M.; Maulik, N. Resveratrol enhances neovascularization in the infarcted rat myocardium through the induction of thioredoxin-1, heme oxygenase- 1 and vascular endothelial growth factor. J. Mol. Cell. Cardiol. 2005, 39, 813-822.

58. Cullen, J.P.; Morrow, D.; Jin, Y.; von Offenberg Sweeney, N.; Sitzmann, J.V.; Cahill, P.A.; Redmond, E.M. Resveratrol inhibits expression and binding activity of the monocyte chemotactic protein-1 receptor, CCR2, on THP-1 monocytes. Atherosclerosis 2007, (in press)

59. Wang, S.; Wang, X.; Yan, J.; Xie, X.; Fan, F.; Zhou, X.; Han, L.; Chen, J. Resveratrol inhibits proliferation of cultured rat cardiac fibroblasts: Correlated with NO-cGMP signaling pathway. Eur. J. Pharmacol. 2007, 567, 26-35.

60. Steffen, Y.; Wiswedel, I.; Peter, D.; Schewe, T.; Sies, H. Cytotoxicity of myeloperoxidase/nitriteoxidized low-density lipoprotein toward endothelial cells is due to a high $7 \beta$-hydroxycholesterol to 7-ketocholesterol ratio. Free Radic. Biol. Med. 2006, 41, 1139-1150.

61. Petroni, A.; Blasevich, M.; Salami, M.; Papini, N.; Montedoro, G.F.; Galli, C. Inhibition of platelet aggregation and eicosanoid production by phenolic components of olive oil. Thromb. Res. 1995, 78, 151-160.

62. Léger, C.L.; Carbonneau, M.A.; Michel, F.; Mas, E.; Monnier, L.; Cristol, J.P.; Descomps, B. A thromboxane effect of a hydroxytyrosol-rich olive oil wastewater extract in patients with uncomplicated type I diabetes. Eur. J. Clin. Nutr. 2005, 59, 727-730.

63. de La Puerta, R.; Ruiz-Gutierrez, V.; Hoult, J.R. Inhibition of leukocyte 5-lipoxygenase by phenolics from virgin olive oil. Biochem. Pharmacol. 1999, 57, 445-449.

64. Carluccio, M.A.; Siculella, L.; Ancora, M.A.; Massaro, M.; Scoditti, E.; Storelli, C.; Visioli, F.; Distante, A.; De Caterina, R. Olive oil and red wine antioxidant polyphenols inhibit endothelial activation: antiatherogenic properties of Mediterranean diet phytochemicals. Arterioscler. Thromb. Vasc. Biol. 2003, 23, 622-629.

65. Manna, C.; Migliardi, V.; Golino, P.; Scognamiglio, A.; Galletti, P.; Chiariello, M.; Zappia, V. Oleuropein prevents oxidative myocardial injury induced by ischemia and reperfusion. $J$. Nutr. Biochem. 2004, 15, 461-466.

66. Gouedard, C.; Barouki, R.; Morel, Y. Dietary polyphenols increase paraoxonase 1 gene expression by an aryl hydrocarbon receptor-dependent mechanism. Mol. Cell Biol. 2004, 24, 5209-5222.

67. Nair, M.P.; Kandaswami, C.; Mahajan, S.; Chadha, K.C.; Chawda, R.; Nair, H.; Kumar, N.; Nair, R.E.; Schwartz, S.A. The flavonoid, quercetin, differentially regulates Th-1 (IFN gamma) and Th2 (IL4) cytokine gene expression by normal peripheral blood mononuclear cells. Biochim. Biophys. Acta 2002, 1593, 29-36.

68. Myhrstad, M.C.; Carlsen, H.; Nordstrom, O.; Blomhoff, R.; Moskaug, J.O. Flavonoids increase the intracellular glutathione level by transactivation of the gamma-glutamylcysteine synthetase catalytical subunit promoter. Free Radic. Biol. Med. 2002, 32, 386-393.

69. Lo, H.M.; Hung, C.F.; Huang, Y.Y.; Wu, W.B. Tea polyphenols inhibit rat vascular smooth muscle cell adhesion and migration on collagen and laminin via interference with cell-ECM interaction. J. Biomed. Sci. 2007, (in press)

70. Mizushige, T.; Mizushige, K.; Miyatake, A.; Kishida, T.; Ebihara, K. Inhibitory effects of soy isoflavones on cardiovascular collagen accumulation in rats. J. Nutr. Sci. Vitaminol. (Tokyo) 2007, $53,48-52$. 
71. Tikkanen, M.J.; Adlercreutz, H. Dietary soy-derived isoflavone phytoestrogens. Could they have a role in coronary heart disease prevention? Biochem.Pharmacol. 2000, 60, 1-5.

72. Schramm, D.D.; Wang, J.F.; Holt, R.R.; Ensunsa, J.L.; Gonsalves, J.L.; Lazarus, S.A.; Schmitz, H.H.; German, J.B.; Keen, C.L. Chocolate procyanidins decrease the leukotriene-prostacyclin ratio in humans and human aortic endothelial cells. Am. J. Clin. Nutr. 2001, 73, 36-40.

73. Dedoussis, G.V.; Kaliora, A.C.; Psarras, S.; Chiou, A.; Mylona, A.; Papadopoulos, N.G.; Andrikopoulos, N.K. Antiatherogenic effect of Pistacia lentiscus via GSH restoration and downregulation of CD36 mRNA expression. Atherosclerosis 2004, 174, 293-303.

74. Sato, M.; Bagchi, D.; Tosaki, A.; Das, D.K. Grape seed proanthocyanidin reduces cardiomyocyte apoptosis by inhibiting ischemia-reperfusion-induced activation of JNK-1 and c-JUN. Free Radic. Biol. Med. 2001, 31, 729-737.

75. Dasgupta, B.; Milbrandt, J. Resveratrol stimulates AMP kinase activity in neurons. Proc. Natl. Acad. Sci. U. S. A. 2007, 104, 7217-7222.

76. Chavez, E.; Reyes-Gordillo, K.; Segovia, J.; Shibayama, M.; Tsutsumi, V.; Vergara, P.; Moreno, M.G.; Muriel, P. Resveratrol prevents fibrosis, NF-kappaB activation and TGF-beta increases induced by chronic $\mathrm{CCl}$ (4) treatment in rats. J. Appl. Toxicol. 2007, (in press)

77. Bastianetto, S.; Brouillette, J.; Quirion, R. Neuroprotective effects of natural products: interaction with intracellular kinases, amyloid peptides and a possible role for transthyretin. Neurochem. Res. 2007, (in press)

78. Okawara, M.; Katsuki, H.; Kurimoto, E.; Shibata, H.; Kume, T.; Akaike, A. Resveratrol protects dopaminergic neurons in midbrain slice culture from multiple insults. Biochem. Pharmacol. 2007, $73,550-560$.

79. Kim, S.J.; Jeong, H.J.; Lee, K.M.; Myung, N.Y.; An, N.H.; Mo Yang, W.; Kyu Park, S.; Lee, H.J.; Hong, S.H.; Kim, H.M.; Um, J.Y. Epigallocatechin-3-gallate suppresses NF-kappaB activation and phosphorylation of p38 MAPK and JNK in human astrocytoma U373MG cells. J. Nutr. Biochem. 2007, (in press)

80. de Boer, V.C.; de Goffau, M.C.; Arts, I.C.; Hollman, P.C.; Keijer, J. SIRT1 stimulation by polyphenols is affected by their stability and metabolism. Mech. Ageing Dev. 2006, 127, 618-627.

81. Levites, Y.; Amit, T.; Youdim, M.B.; Mandel, S. Involvement of protein kinase C activation and cell survival/cell cycle genes in green tea polyphenol (-)-epigallocatechin-3-gallate neuronprotective action. J. Biol. Chem. 2002, 277, 30574-30580.

82. Mercer, L. D.; Kelly, B.L.; Horne, M. K.; Beart, P.M. Dietary polyphenols protect dopamine neurons from oxidative insults and apoptosis: investigations in primary rat mesencephalic cultures. Biochem. Pharmacol. 2005, 69, 339-345.

83. Schroeter, H.; Spencer, J.P.; Rice-Evans, C.; Williams, R.J. Flavonoids protect neurons from oxidized low-density lipoprotein-induced apoptosis involving c-Jun N-terminal kinase (JNK), cjun and caspase-3. Biochem. J. 2001, 358, 547-557.

84. Garcia-Alloza, M.; Borrelli, L.A.; Rozkalne, A.; Hyman, B.T.; Bacskai, B.J. Curcumin labels amyloid pathology in vivo, disrupts existing plaques, and partially restores distorted neurites in an Alzheimer mouse model. J. Neurochem. 2007, 102, 1095-1104. 
85. Mao, T.K.; Powell, J.; Van de Water, J.; Keen, C.L.; Schmitz, H.H.; Hammerstone, J.F.; Eric Gershwin, M. The effect of cocoa procyanidins on the transcription and secretion of interleukin $1 \beta$ in peripheral blood mononuclear cells. Life Sci. 2000, 66, 1377-1386.

86. Kawai, K.; Tsuno, N.H.; Kitayama, J.; Okaji, Y.; Yazawa, K.; Asakage, M.; Sasaki, S.; Watanabe, T.; Takahashi, K.; Nagawa, H. Epigallocatechin gallate induces apoptosis of monocytes. J. Allergy Clin. Immunol. 2005, 115, 186-191.

87. Kawai, K.; Tsuno, N.H.; Kitayama, J.; Okaji, Y.; Yazawa, K.; Asakage, M.; Hori, N.; Watanabe, T.; Takahashi, K.; Nagawa, H. Epigallocatechin gallate attenuates adhesion and migration of CD8+ T cells by binding to CD11b. J. Allergy Clin. Immunol. 2004, 113, 1211-1217.

88. Shakibaei, M.; John, T.; Seifarth, C.; Mobasheri, A. Resveratrol inhibits IL-1beta-induced stimulation of caspase-3 and cleavage of PARP in human articular chondrocytes in vitro. Ann. N. Y. Acad. Sci. 2007, 1095, 554-563.

89. Tsai, S.H.; Lin-Shiau, S.Y.; Lin, J.K. Suppression of nitric oxide synthase and the downregulation of the activation of NF-אB in macrophages by resveratrol. Br. J. Pharmacol. 1999, 126, 673-680.

90. Nonn, L.; Duong, D.; Peehl, D.M. Chemopreventive anti-inflammatory activities of curcumin and other phytochemicals mediated by MAP kinase phosphatase-5 in prostate cells. Carcinogenesis 2007, 28, 1188-1196.

91. Gerritsen, M.E.; Carley, W.W.; Ranges, G.E.; Shen, C.P.; Phan, S.A.; Ligon, G.F.; Perry, C.A. Flavonoids inhibit cytokine-induced endothelial cell adhesion protein gene expression. Am. J. Pathol. 1995, 147, 278-292.

92. Choi, J.S.; Choi, Y.J.; Park, S.H.; Kang, J.S.; Kang, Y.H. Flavones mitigate tumor necrosis factoralpha-induced adhesion molecule upregulation in cultured human endothelial cells: role of nuclear factor-kappa B. J. Nutr. 2004, 134, 1013-1019.

93. van Meeteren, M.E.; Hendriks, J.J.; Dijkstra, C.D.; van Tol, E.A. Dietary compounds prevent oxidative damage and nitric oxide production by cells involved in demyelinating disease. Biochem. Pharmacol. 2004, 67, 967-975.

94. Youdim, K.A.; McDonald, J.; Kalt, W.; Joseph, J.A. Potential role of dietary flavonoids in reducing microvascular endothelium vulnerability to oxidative and inflammatory insults. $J$. Nutr. Biochem. 2002, 13, 282-288.

95. Camacho-Barquero, L.; Villegas, I.; Sanchez-Calvo, J.M.; Talero, E.; Sanchez-Fidalgo, S.; Motilva, V.; Alarcon de la Lastra, C. Curcumin, a Curcuma longa constituent, acts on MAPK p38 pathway modulating COX-2 and iNOS expression in chronic experimental colitis. Int. Immunopharmacol. 2007, 7, 333-342.

96. Rahman I, Biswas SK, Kirkham PA.Regulation of inflammation and redox signaling by dietary polyphenols. Biochem. Pharmacol. 2006, 72, 1439-1452.

97. Kim, H.Y.; Park, E.J.; Joe, E.H.; Jou, I. Curcumin suppresses Janus kinase-STAT inflammatory signaling through activation of src homology 2 domain-containing tyrosine phosphatase 2 in brain microglia. J. Immunol. 2003, 171, 6072-6079.

98. Fabiani, R.; De Bartolomeo, A.; Rosignoli, P.; Servili, M.; Montedoro, G.F.; Morozzi, G. Cancer chemoprevention by hydroxytyrosol isolated from virgin olive oil through G1 cell cycle arrest and apoptosis. Eur. J. Cancer Prev. 2002, 11, 351-358. 
99. Fuggetta, M.P.; Lanzilli, G.; Tricarico, M.; Cottarelli, A.; Falchetti, R.; Ravagnan, G.; Bonmassar, E. Effect of resveratrol on proliferation and telomerase activity of human colon cancer cells in vitro. J. Exp. Clin. Cancer Res. 2006, 25, 189-193.

100. Kuo, P.L.; Chiang, L.C.; Lin, C.C. Resveratrol-induced apoptosis is mediated by p53-dependent pathway in HepG2 cells. Life Sci. 2002, 72, 23-34.

101. Pozo-Guisado, E.; Lorenzo-Benayas, M.J.; Fernandez-Salguero, P.M. Resveratrol modulates the phosphoinositide 3-kinase pathway through an estrogen receptor alpha-dependent mechanism: relevance in cell proliferation. Int. J. Cancer 2004, 109,167-173.

102. Kundu, J.K.; Chun, K.S.; Kim, S.O.; Surh, Y.J. Resveratrol inhibits phorbol ester-induced cyclooxygenase-2 expression in mouse skin: MAPKs and AP-1 as potential molecular targets. Biofactors 2004, 21, 33-39.

103. Yoon, S.H.; Kim, Y.S.; Ghim, S.Y.; Song, B.H.; Bae, Y.S. Inhibition of protein kinase CKII activity by resveratrol, a natural compound in red wine and grapes. Life Sci. 2002, 71, 2145-2152.

104. Slater, S.J.; Seiz, J.L.; Cook, A.C.; Stagliano, B.A.; Buzas, C.J. Inhibition of protein kinase C by resveratrol. Biochim. Biophys. Acta 2003, 1637, 59-69.

105. Li, H.; Cheng, Y.; Wang, H.; Sun, H.; Liu, Y.; Liu, K.; Peng, S. Inhibition of nitrobenzeneinduced DNA and hemoglobin adductions by dietary constituents. Appl. Radiat. Isot. 2003, 58, 291-298.

106. Grace, S.C.; Salgo, M.G.; Pryor, W.A. Scavenging of peroxynitrite by a phenolic/peroxidase system prevents oxidative damage to DNA. FEBS Lett. 1998, 426, 24-28.

107. Lee, L.T.; Huang, Y.T.; Hwang, J.J.; Lee, P.P.; Ke, F.C.; Nair, M.P.; Kanadaswam, C.; Lee, M.T. Blockade of the epidermal growth factor receptor tyrosine kinase activity by quercetin and luteolin leads to growth inhibition and apoptosis of pancreatic tumor cells. Anticancer Res. 2002, $22,1615-1627$.

108. Cooray, H.C.; Janvilisri, T.; van Veen, H.W.; Hladky, S.B. and Barrand, M.A. Interaction of the breast cancer resistance protein with plant polyphenols. Biochem. Biophys. Res. Commun. 2004, 317, 269-275.

109. Kunnumakkara, A.B.; Guha, S.; Krishnan, S.; Diagaradjane, P.; Gelovani, J.; Aggarwal, B.B. Curcumin potentiates antitumor activity of gemcitabine in an orthotopic model of pancreatic cancer through suppression of proliferation, angiogenesis, and inhibition of nuclear factorkappaB-regulated gene products. Cancer Res. 2007, 67, 3853-3861.

110. Collett, G.P.; Campbell, F.C. Curcumin induces c-jun N-terminal kinase-dependent apoptosis in HCT116 human colon cancer cells. Carcinogenesis 2004, 25, 2183-2189.

111. Anto, R.J.; Mukhopadhyay, A.; Denning, K.; Aggarwal, B.B. Curcumin (diferuloylmethane) induces apoptosis through activation of caspase-8, BID cleavage and cytochrome c release: its suppression by ectopic expression of Bcl-2 and Bcl-xL. Carcinogenesis 2002, 23, 143-150.

112. Aoki, H.; Takada, Y.; Kondo, S.; Sawaya, R.; Aggarwal, B.; Kondo, Y. Aoki, H.; Takada, Y.; Kondo, S.; Sawaya, R.; Aggarwal, B.; Kondo, Y. Evidence that curcumin suppresses the growth of malignant gliomas in vitro and in vivo through induction of autophagy: role of Akt and ERK signaling pathways. Mol. Pharmacol. 2007, 72, 29-39. 
113. Nardini, M.; Leonardi, F.; Scaccini, C.; Virgili, F. Modulation of ceramide-induced NF- $\mathrm{B}$ binding activity and apoptotic response by caffeic acid in U937 cells: comparison with other antioxidants. Free Radic. Biol. Med. 2001, 30, 722-733.

114. Naasani, I.; Oh-Hashi, F.; Oh-Hara, T.; Feng, W.Y.; Johnston, J.; Chan, K.; Tsuruo, T. Blocking telomerase by dietary polyphenols is a major mechanisms for limiting the growth of human cancer cells in vitro and in vivo. Cancer Res. 2003, 63, 824-830.

115. Jung, J.Y.; Mo, H.C.; Yang, K.H.; Jeong, Y.J.; Yoo, H.G.; Choi, N.K.; Oh, W.M.; Oh, H.K.; Kim, S.H.; Lee, J.H.; Kim, H.J.; Kim, W.J. Inhibition by epigallocatechin gallate of CoCl2induced apoptosis in rat PC12 cells. Life Sci. 2007, 80, 1355-1363.

116. Khanduja, K.L.; Avti, P.K.; Kumar, S.; Mittal, N.; Sohi, K.K.; Pathak, C.M. Anti-apoptotic activity of caffeic acid, ellagic acid and ferulic acid in normal human peripheral blood mononuclear cells: A Bcl-2 independent mechanism. Biochim. Biophys. Acta 2006, 1760, $283-$ 289.

117. Choi, Y.J.; Jeong, Y.J.; Lee, Y.J.; Kwon, H.M.; Kang, Y.H. (-) Epigallocatechin gallate and quercetin enhance survival signaling in response to oxidant-induced human endothelial apoptosis. J. Nutr. 2005, 135, 707-713.

118. Bharti, A.C.; Donato, N.; Aggarwal, B.B. Curcumin (diferuloylmethane) inhibits constitutive and IL-6-inducible STAT3 phosphorylation in human multiple myeloma cells. J. Immunol. 2003, 171, 3863-3871.

119. Yuste, P.; Longstaff, M.; McCorquodale, C. The effect of proanthocyanidin-rich hulls and proanthocyanidin extracts from bean (Vicia faba L.) hulls on nutrient digestibility and digestive enzyme activities in young chicks. Br. J. Nutr. 1992, 67, 57-65.

120. Longstaff, M.; McNab, J.M. The inhibitory effects of hull polysaccharides and tannins of field beans (Vicia faba L.) on the digestion of amino acids, starch and lipid and on digestive enzyme activities in young chicks. Br. J. Nutr. 1991, 65, 199-216.

121. Sbarra, V.; Ristorcelli, E.; Petit-Thevenin, J.L.; Teissedre, P.L.; Lombardo, D.; Verine, A. In vitro polyphenol effects on activity, expression and secretion of pancreatic bile salt-dependent lipase. Biochim. Biophys. Acta 2005, 1736, 67-76.

122. Aggarwal, B.B.; Shisodia, S. Suppression of the nuclear factorkappaB activation pathway by spice-derived phytochemicals: reasoning for seasoning. Ann. N.Y. Acad. Sci. 2004, 1030, 434441.

123. Hanamura, T.; Hagiwara, T.; Kawagishi, H. Structural and functional characterization of polyphenols isolated from acerola (Malpighia emarginata DC.) fruit. Biosci. Biotechnol. Biochem. 2005, 69, 280-286.

124. Youn, H.S.; Saitoh, S.I.; Miyake, K.; Hwang, D.H. Inhibition of homodimerization of Toll-like receptor 4 by curcumin. Biochem. Pharmacol. 2006, 72, 62-69.

125. Pan, M.H.; Lin-Shiau, S.Y.; Lin, J.K. Comparative studies on the suppression of nitric oxide synthase by curcumin and its hydrogenated metabolites through down-regulation of IkappaB kinase and NFkappaB activation in macrophages. Biochem. Pharmacol. 2000, 60, 1665-1676.

126. Kang, G.; Kong, P.J.; Yuh, Y.J.; Lim, S.Y.; Yim, S.V.; Chun, W.; Kim, S.S. Curcumin suppresses lipopolysaccharide-induced cyclooxygenase-2 expression by inhibiting activator 
protein 1 and nuclear factor kappaB bindings in BV2 microglial cells. J. Pharmacol. Sci. 2004, 94, 325-328.

127. Kluth, D.; Banning, A.; Paur, I.; Blomhoff, R.; Brigelius-Flohe, R. Modulation of pregnane X receptor-and electrophile responsive element-mediated gene expression by dietary polyphenolic compounds. Free Radic. Biol. Med. 2007, 42, 315-325.

128. Meeran, S.M.; Katiyar, S.K. Grape seed proanthocyanidins promote apoptosis in human epidermoid carcinoma A431 cells through alterations in Cdki-Cdk-cyclin cascade, and caspase-3 activation via loss of mitochondrial membrane potential. Exp. Dermatol. 2007, 16, 405-415.

129. Sharma, S.D.; Meeran, S.M.; Katiyar, S.K. Dietary grape seed proanthocyanidins inhibit UVBinduced oxidative stress and activation of mitogen-activated protein kinases and nuclear factorkappaB signaling in in vivo SKH-1 hairless mice. Mol. Cancer Ther. 2007, 6, 995-1005.

130. Spencer, J.P.; Rice-Evans, C.; Williams, R.J. Modulation of pro-survival Akt/PKB and ERK1/2 signalling cascades by quercetin and its in vivo metabolites underlie their action on neuronal viability. J. Biol. Chem. 2003, 278, 34783-34793.

131. Joy, S.; Siow, R.C.; Rowlands, D.J.; Becker, M.; Wyatt, A.W.; Aaronson, P.I.; Coen, C.W.; Kallo, I.; Jacob, R.; Mann, G.E. The isoflavone Equol mediates rapid vascular relaxation: Ca2+independent activation of endothelial nitric-oxide synthase/Hsp90 involving ERK1/2 and Akt phosphorylation in human endothelial cells. J. Biol. Chem. 2006, 281, 27335-27345.

132. Chen, C.Y.; Jang, J.H.; Li, M.H.; Surh, Y.J. Resveratrol upregulates heme oxygenase-1 expression via activation of NF-E2-related factor 2 in PC12 cells. Biochem. Biophys. Res. Commun. 2005, 331, 993-1000.

133. Oak, M.H.; Chataigneau, M.; Keravis, T.; Chataigneau, T.; Beretz, A.; Andriantsitohaina, R.; Stoclet, J.C.; Chang, S.J.; Schini-Kerth, V.B. Red wine polyphenolic compounds inhibit vascular endothelial growth factor expression in vascular smooth muscle cells by preventing the activation of the p38 mitogen-activated protein kinase pathway. Arterioscler. Thromb. Vasc. Biol. 2003, 23, 1001-1007.

134. Oak, M.H.; El Bedoui, J.; Anglard, P.; Schini-Kerth, V.B. Red wine polyphenolic compounds strongly inhibit pro-matrix metalloproteinase-2 expression and its activation in response to thrombin via direct inhibition of membrane type 1-matrix metalloproteinase in vascular smooth muscle cells. Circulation 2004, 110, 1861-1867

135. Iijima, K.; Yoshizumi, M.; Hashimoto, M.; Akishita, M.; Kozaki, K.; Ako, J.; Watanabe, T.; Ohike, Y.; Son, B.; Yu, J.; Nakahara, K.; Ouchi, Y. Red wine polyphenols inhibit vascular smooth muscle cell migration through two distinct signaling pathways. Circulation 2002, 105, 2404-2410.

136. Ndiaye, M.; Chataigneau, T.; Chataigneau, M.; Schini-Kerth, V.B. Red wine polyphenols induce EDHF-mediated relaxations in porcine coronary arteries through the redox-sensitive activation of the PI3-kinase/Akt pathway. Br. J. Pharmacol. 2004, 142, 1131-1136.

137. Martin, S.; Andriambeloson, E.; Takeda, K.; Andriantsitohaina, R. Red wine polyphenols increase calcium in bovine aortic endothelial cells: a basis to elucidate signalling pathways leading to nitric oxide production. Br. J. Pharmacol. 2002, 135, 1579-1587.

138. Jiménez, R.; López-Sepúlveda, R.; Kadmiri, M.; Romero, M.; Vera, R.; Sánchez, M.; Vargas, F.; O'valle, F.; Zarzuelo, A.; Dueñas, M.; Santos-Buelga, C.; Duarte, J. Polyphenols restore 
endothelial function in DOCA-salt hypertension: Role of endothelin-1 and NADPH oxidase. Free Radic. Biol. Med. 2007, 43, 462-473.

139. Khan, N.Q.; Lees, D.M.; Douthwaite, J.A.; Carrier, M.J.; Corder, R. Comparison of red wine extract and polyphenol constituents on endothelin-1 synthesis by cultured endothelial cells. Clin. Sci. (Lond). 2002, 103 Suppl 48, 72S-75S.

140. Wollny, T.; Chabielska, E.; Malinowska-Zaprzałka, M.; Nazarko, J.; Rozmysłowicz-Szermińska, W.; Buczko, W. Effects of Bulgarian red and white wines on primary hemostasis and experimental thrombosis in rats. Pol. J. Pharmacol. 2003, 55, 1089-1096.

141. Dell'Agli, M.; Busciala, A.; Bosisio, E. Vascular effects of wine polyphenols. Cardiovasc. Res. 2004, 63, 593-602.

142. Xu, J.W.; Ikeda, K.; Yamori, Y. Cyanidin-3-glucoside regulates phosphorylation of endothelial nitric oxide synthase. FEBS Lett. 2004, 574, 176-180.

143. Kim, J.A.; Formoso, G.; Li, Y.; Potenza, M.A.; Marasciulo, F.L.; Montagnani, M.; Quon, M.J. Epigallocatechin gallate, a green tea polyphenol, mediates NO-dependent vasodilation using signaling pathways in vascular endothelium requiring reactive oxygen species and Fyn. J. Biol. Chem. 2007, 282, 13736-13745.

144. Lorenz, M.; Wessler, S.; Follmann, E.; Michaelis, W.; Düsterhöft, T.; Baumann, G.; Stangl, K.; Stangl, V. A constituent of green tea, epigallocatechin-3-gallate, activates endothelial nitric oxide synthase by a phosphatidylinositol-3-OH-kinase-, cAMP-dependent protein kinase-, and Aktdependent pathway and leads to endothelial-dependent vasorelaxation. J. Biol. Chem. 2004, 279, 6190-6195.

145. Maiti, T.K.; Chatterjee, J. and Dasgupta, S. Effect of green tea polyphenols on angiogenesis induced by an angiogenin-like protein. Biochem. Biophys. Res. Commun. 2003,308, 64-67.

146. Kalin, R.; Righi, A.; Del Rosso, A.; Bagchi, D.; Generini. S.; Cerinic, M.M.; Das, D.K. Activin, a grape seed-derived proanthocyanidin extract, reduces plasma levels of oxidative stress and adhesion molecules (ICAM-1, VCAM-1 and E-selectin) in systemic sclerosis. Free Radic. Res. 2002, 36, 819-825.

147. Sen, C.K.; Bagchi, D. Regulation of inducible adhesion molecule expression in human endothelial cells by grape seed proanthocyanidin extract. Mol. Cell Biochem. 2001, 216, 1-7.

148. Actis-Goretta, L.; Ottaviani, J.I.; Keen, C.L.; Fraga, C.G. Inhibition of angiotensin converting enzyme (ACE) activity by flavan-3-ols and procyanidins. FEBS Lett. 2003, 555, 597-600.

149. Alvarez, P.; Alvarado, C.; Puerto, M.; Schlumberger, A.; Jiménez, L.; De la Fuente, M. Improvement of leukocyte functions in prematurely aging mice after five weeks of diet supplementation with polyphenol-rich cereals. Nutrition 2006, 22, 913-921.

150. Bhattacharyya, S.; Mandal, D.; Saha, B.; Sen, G.S.; Das, T.; Sa, G. Curcumin prevents tumorinduced $\mathrm{T}$ cell apoptosis through Stat-5a-mediated Bcl-2 induction. J.Biol.Chem. 2007, 282, 15954-15964.

151. Akiyama, H.; Sato, Y.; Watanabe, T.; Nagaoka, M.H.; Yoshioka, Y.; Shoji, T.; Kanda, T.; Yamada, K.; Totsuka, M.; Teshima, R.; Sawada, J.; Goda, Y.; Maitani, T. Dietary unripe apple polyphenol inhibits the development of food allergies in murine models. FEBS Lett. 2005, 579, 4485-4491. 
152. Kanda, T.; Akiyama, H.; Yanagida, A.; Tanabe, M.; Goda, Y.;Toyoda, M.; Teshima, R.; Saito, Y. Inhibitory effects of apple polyphenol on induced histamine release from RBL-2H3 cells and rat mast cells. Biosci. Biotechnol. Biochem. 1998, 62, 1284-1289.

153. Kowluru, R.A.; Kanwar, M. Effects of curcumin on retinal oxidative stress and inflammation in diabetes. Nutr Metab (London) 2007, 4, 8.

154. Johnston, K.; Sharp, P.; Clifford, M.; Morgan, L. Dietary polyphenols decrease glucose uptake by human intestinal Caco-2 cells. FEBS Lett. 2005, 579, 1653-1657.

155. Kobayashi, Y.; Suzuki, M.; Hideo, S.; Arai, S.; Yukihiko, H.; Suzuki, K.; Miyamoto, Y.; Shimizu, M. Green tea polyphenols inhibit the sodium-dependent glucose transporter of intestinal epithelial cells by a competitive mechanism. J. Agric. Food Chem. 2000, 48, 5618-5623.

156. Song, J.; Kwon, O.; Chen, S.; Daruwala, R.; Eck, P.; Park, J.B.; Levine, M. Flavonoid inhibition of SVCT1 and GLUT2, intestinal transporters for vitamin C and glucose. J. Biol. Chem. 2002, 277, 15252-15260.

157. Yoshikawa, M.; Nishida, N.; Shimoda, H.; Takada,M.; Kawahara, Y.; Matsuda, H. Polyphenol constituents from Salacia species: quantitative analysis of mangiferin with alpha-glucosidase and aldose reductase inhibitory activities. Yakugaku Zasshi 2001, 121, 371-378.

158. McDougall GJ, Shpiro F, Dobson P, Smith P, Blake A, Stewart D. Different polyphenolic components of soft fruits inhibits alpha-amylase and alpha-glucosidase. J. Agric. Food Chem. 2005, 53, 2760-2766.

159. Bhat, K.P.; Lantvit, D.; Christov, K.; Mehta, R.G.; Moon, R.C.; Pezzuto, J.M. Estrogenic and antiestrogenic properties of resveratrol in mammary tumor models. Cancer Res. 2001, 61, 74567463.

160. Bhat, K.P.; Pezzuto, J.M. Resveratrol exhibits cytostatic and antiestrogenic properties with human endometrial adenocarcinoma (Ishikawa) cells. Cancer Res. 2001, 61, 6137-6144.

161. Otake, Y.; Nolan, A.L.; Walle, U.K.; Walle, T. Quercetin and resveratrol potently reduce estrogen sulfotransferase activity in normal human mammary epithelial cells. J. Steroid Biochem. Mol. Biol. 2000, 73, 265-270.

162. Reidenberg, M.M. Environmental inhibition of 11b-hydroxysteroid dehydrogenase. Toxicology 2000, 144, 107-111.

163. Kuo, P.L.; Chiang, L.C.; Lin, C.C. Resveratrol-induced apoptosis is mediated by p53-dependent pathway in HepG2 cells. Life Sci. 2002, 72, 23-34.

164. Ahmad, N.; Adhami, V. M.; Afaq, F.; Feyes, D. K.; Mukhtar, H. Resveratrol causesWAF-1/p21mediated G (1)-phase arrest of cell cycle and induction of apoptosis in human epidermoid carcinoma A431 cells. Clin. Cancer Res. 2001, 7, 1466-1473.

165. Wolter, F.; Akoglu, B.; Clausnitzer, A.; Stein, J. Downregulation of the cyclin D1/Cdk4 complex occurs during resveratrol-induced cell cycle arrest in colon cancer cell lines. J. Nutr. 2001, 131, 2197-2203.

166. Adhami, V.M.; Afaq, F.; Ahmad, N. Involvement of the retinoblastoma (pRb)-E2F/DP pathway during antiproliferative effects of resveratrol in human epidermoid carcinoma (A431) cells. Biochem. Biophys. Res. Commun. 2001, 288, 579-585. 
167. Joe, A.K.; Liu, H.; Suzui, M.; Vural, M. E.; Xiao, D.; Weinstein, I. B. Resveratrol induces growth inhibition, S-phase arrest, apoptosis, and changes in biomarker expression in several human cancer cell lines. Clin. Cancer Res. 2002, 8, 893-903.

168. Poussier, B.; Cordova, A.C.; Becquemin, J.P.; Sumpio, B.E. Resveratrol inhibits vascular smooth muscle cell proliferation and induces apoptosis. J. Vasc. Surg. 2005, 42, 1190-1197.

169. Larrosa, M,; Tomas-Barberan, F.A.; Espin, J.C. Grape polyphenol resveratrol and the related molecule 4-hydroxystilbene induce growth inhibition, apoptosis, S-phase arrest, and upregulation of cyclins A, E, and B1 in human SK-Mel-28 melanoma cells. J. Agric. Food Chem. 2003, 51, 4576-4584.

170. Meeran, S.M.; Katiyar, S.K. Grape seed proanthocyanidins promote apoptosis in human epidermoid carcinoma A431 cells through alterations in Cdki-Cdk-cyclin cascade, and caspase-3 activation via loss of mitochondrial membrane potential. Exp. Dermatol. 2007, 16, 405-415.

171. Donnelly, L.E.; Newton, R.; Kennedy, G.E.; Fenwick, P.S.; Leung, R.H.; Ito, K.; Russell, R.E.; Barnes, P.J. Anti-inflammatory effects of resveratrol in lung epithelial cells: molecular mechanisms. Am. J. Physiol. Lung Cell Mol. Physiol. 2004, 287, L774- L783.

172. Rahman, I.; Kilty, I. Antioxidant therapeutic targets in COPD. Curr. Drug Targets 2006, 7, $707-$ 720.

173. Xu, M.; Deng, B.; Chow, Y.L.; Zhao, Z.Z.; Hu, B. Effects of curcumin in treatment of experimental pulmonary fibrosis: a comparison with hydrocortisone. J Ethnopharmacol. 2007, 112, 292-299.

174. Sakagami, Y.; Sawabe, A.; Komemushi, S.; All, Z.; Tanaka, T.; Iliya, I.; Iinuma, M. Antibacterial activity of stilbene oligomers against vancomycin-resistant Enterococci (VRE) and methicillinresistant Staphylococcus aureus (MRSA) and their synergism with antibiotics. Biocontrol Sci. 2007, 12, 7-14.

175. Furneri, P.M.; Piperno, A.; Sajia, A.; Bisignano, G. Antimycoplasmal activity of hydroxytyrosol. Antimicrob. Agents Chemother. 2004, 48, 4892-4894.

176. Nair, M.P.; Kandaswami, C.; Mahajan, S.; Nair, H.N.; Chawda, R.; Shanahan, T.; Schwartz, S.A. Grape seed extract proanthocyanidins downregulate HIV-1 entry coreceptors, CCR2b, CCR3 and CCR5 gene expression by normal peripheral blood mononuclear cells. Biol. Res. 2002, 35, 421431.

177. Khanna, S.; Roy, S.; Bagchi, D.; Bagchi, M.; Sen, C.K. Upregulation of oxidant-induced VEGF expression in cultured keratinocytes by a grape seed proanthocyanidin extract. Free Radic. Biol. Med. 2001, 31, 38-42.

178. Ray, S.D.; Kumar, M.A.; Bagchi, D. A novel proanthocyanidin IH636 grape seed extract increases in vivo Bcl-XL expression and prevents acetaminophen-induced programmed and unprogrammed cell death in mouse liver. Arch. Biochem. Biophys. 1999, 369, 42-58.

179. Wong, M.C.; Portmann, B.; Sherwood, R.; Niemela, O.; Koivisto, H.; Parkkila, S.; Trick, K.; L'abbe, M.R.; Wilson, J.; Dash, P.R.; Srirajaskanthan, R.; Preedy, V.R.; Wiseman, H. The cytoprotective effect of alpha-tocopherol and daidzein against d-galactosamine-induced oxidative damage in the rat liver. Metabolism 2007, 56, 865-875. 
180. Kuzu, N.; Metin, K.; Dagli, A.F.; Akdemir, F.; Orhan, C.; Yalniz, M.; Ozercan, I.H.; Sahin, K.; Bahcecioglu, I.H. Protective role of genistein in acute liver damage induced by carbon tetrachloride. Mediators Inflamm. 2007, 2007, 36381.

181. Rucinska, A.; Kirko, S.; Gabryelak, T. Effect of the phytoestrogen, genistein-8-C-glucoside, on Chinese hamster ovary cells in vitro. Cell Biol. Int. 2007, (in press).

182. Galati, G.; Sabzevari, O.; Wilson, J.X.; O’Brien, P.J. Prooxidant activity and cellular effects of the phenoxyl radicals of dietary flavonoids and other polyphenolics. Toxicology 2002, 177, 91104.

183. Rietjens, I.M.C.M.; Boersma, M.G.; de Haan, L.; Spenkelink, B.; Awad, H.M.; Cnubben, N.H.P.; van Zanden, J.J.; van der Woude, H.; Alink, G.M.; Koeman, J. H. The pro-oxidant chemistry of the natural antioxidants vitamin $\mathrm{C}$, vitamin E, carotenoids and flavonoids. Environ. Toxicol. Pharmacol. 2002, 11, 321-333.

184. Huisman, A.; van de Wiel, A.; Rabelink, T.J.; van Faassen, E.E. Wine polyphenols and ethanol do not significantly scavenge superoxide nor affect endothelial nitric oxide production. J. Nutr. Biochem. 2004, 15, 426-432.

185. Sakihama, Y.; Cohen, M.F.; Grace, S.C.; Yamasaki, H. Plant phenolic antioxidant and prooxidant activities: phenolics-induced oxidative damage mediated by metals in plants. Toxicology 2002, 177, 67-80.

186. Fujisawa, S.; Atsumi, T.; Ishihara, M.; Kadoma, Y. Cytotoxicity, ROS-generation activity and radical-scavenging activity of curcumin and related compounds. Anticancer Res. 2004, 24, 563569.

187. Nemeikaite-Ceniene, A.; Imbrasaite, A.; Sergediene, E.; Cenas, N. Quantitative structure-activity relationships in prooxidant cytotoxicity of polyphenols: role of potential of phenoxyl radical/phenol redox couple. Arch. Biochem. Biophys. 2005, 441, 182-190.

188. Manach, C.; Scalbert, A.; Morand, C.; Rémésy, C.; Jiménez, L. Polyphenols: food sources and bioavailability. Am. J. Clin. Nutr. 2004, 79, 727-747.

189. Manach, C.; Williamson, G.; Morand, C.; Scalbert, A.; Rémésy, C. Bioavailability and bioefficacy of polyphenols in humans. I. Review of 97 bioavailability studies. Am. J. Clin. Nutr. 2005, 81, 230S-242S.

190. Gonthier, M.P.; Donovan, J.L.; Texier, O.; Felgines, C.; Remesy, C.; Scalbert, A. Metabolism of dietary procyanidins in rats. Free Radic. Biol. Med. 2003, 35, 837-844.

191. Seeram, N.P.; Lee, R.; Heber, D. Bioavailability of ellagic acid in human plasma after consumption of ellagitannins from pomegranate (Punica granatum L.) juice. Clin. Chim. Acta 2004, 348, 63-68.

192. Chow, H.H.; Hakim, I.A.; Vining, D.R.; Crowell, J.A.; Ranger-Moore, J.; Chew, W.M.; Celaya, C.A.; Rodney, S.R.; Hara, Y.; Alberts, D.S. Effects of dosing condition on the oral bioavailability of green tea catechins after single-dose administration of Polyphenon $\mathrm{E}$ in healthy individuals. Clin. Cancer Res. 2005, 11, 4627-4633.

193. Henning, S.M.; Niu, Y.; Lee, N.H.; Thames, G.D.; Minutti, R.R.; Wang, H.; Go, V.L.; Heber, D. Bioavailability and antioxidant activity of tea flavanols after consumption of green tea, black tea, or a green tea extract supplement. Am. J. Clin. Nutr. 2004, 80, 1558-1564. 
194. Henning, S.M.; Niu, Y.; Liu, Y.; Lee, N.H.; Hara, Y.; Thames, G.D.; Minutti, R.R.; Carpenter, C.L.; Wang, H.; Heber, D. Bioavailability and antioxidant effect of epigallocatechin gallate administered in purified form versus as green tea extract in healthy individuals. J. Nutr. Biochem. 2005, 16, 610-616.

195. Visioli, F.; Galli, C.; Bornet, F.; Mattei, A.; Patelli, R.; Galli, G.; Caruso, D. Olive oil phenolics are dose-dependently absorbed in humans. FEBS Lett. 2000, 468,159-160.

196. Rasmussen, S.E.; Breinholt, V.M. Non-nutritive bioactive food constituents of plants: bioavailability of flavonoids. Int. J. Vitam. Nutr. Res. 2003, 73, 101-111.

197. Covas, M.I. Olive oil and the cardiovascular system. Pharmacol. Res. 2007, 55, 175-186.

198. Miro-Casas, E.; Covas, M.I.; Farre, M.; Fito, M.; Ortuño, J.; Weinbrenner, T.; Roset, P.; de la Torre, R. Hydroxytyrosol disposition in humans. Clin. Chem. 2003, 49, 945-952.

199. Caruso, D.; Visioli, F.; Patelli, R.; Galli, C.; Galli, G. Urinary excretion of olive oil phenols and their metabolites in humans. Metabolism. 2001, 50, 1426-1428.

200. Tuck, K.L.; Hayball, P.J.; Stupans, I. Structural characterization of the metabolites of hydroxytyrosol, the principal phenolic component in olive oil in rats. J. Agric. Food Chem. 2002, 50, 2404-2409.

201. Corona, G.; Tzounis, X.; Assunta Dessi, M.; Deiana, M.; Debnam, E.S.; Visioli, F.; Spencer, J.P. The fate of olive oil polyphenols in the gastrointestinal tract: implications of gastric and colonic microflora-dependent biotransformation. Free Radic. Res. 2006, 40, 647-658.

202. de la Torre-Carbot, K.; Jauregui, O.; Castellote, A.I.; Lamuela-Raventós, R.M.; Covas, M.I.; Casals, I.; López-Sabater, M.C. Rapid high-performance liquid chromatography-electrospray ionization tandem mass spectrometry method for qualitative and quantitative analysis of virgin olive oil metabolites in human low-density lipoproteins. J. Chromatogr. A. 2006, 1116, 69-75.

203. Carbonaro, M.; Grant, G.; Pusztai, A. Evaluation of polyphenol bioavailability in rat small intestine. Eur. J. Nutr. 2001, 40, 84-90.

(C) 2007 by MDPI (http://www.mdpi.org). Reproduction is permitted for noncommercial purposes. 